\title{
The influence of biogenic emissions from Africa on tropical tropospheric ozone during 2006: a global modeling study
}

\author{
J. E. Williams ${ }^{1}$, M. P. Scheele ${ }^{1}$, P. F. J. van Velthoven ${ }^{1}$, J.-P. Cammas ${ }^{2,3}$, V. Thouret ${ }^{2,3}$, C. Galy-Lacaux ${ }^{3}$, and \\ A. Volz-Thomas ${ }^{4}$ \\ ${ }^{1}$ Royal Netherlands Meteorological Institute, De Bilt, The Netherlands \\ ${ }^{2}$ Université de Toulouse, UPS, LA (Laboratorie d'Aerologie), 31400 Toulouse, France \\ ${ }^{3}$ Laboratorie d'Aeronomie, (UMR UPS/CNRS 5560), Observatoire Midi-Pyrénées, Toulouse, France \\ ${ }^{4}$ Institut für Chemie and Dynamik der Geosphäre II: Troposphäre, Förschungszentrum Jülich, Jülich, Germany
}

Received: 26 March 2009 - Published in Atmos. Chem. Phys. Discuss.: 28 April 2009

Revised: 6 August 2009 - Accepted: 7 August 2009 - Published: 11 August 2009

\begin{abstract}
We have performed simulations using a 3-D global chemistry-transport model to investigate the influence that biogenic emissions from the African continent exert on the composition of the troposphere in the tropical region. For this purpose we have applied two recently developed biogenic emission inventories provided for use in large-scale global models (Granier et al., 2005; Lathière et al., 2006) whose seasonality and temporal distribution for biogenic emissions of isoprene, other volatile organic compounds and NO is markedly different. The use of the 12 year average values for biogenic emissions provided by Lathière et al. (2006) results in an increase in the amount of nitrogen sequestrated into longer lived reservoir compounds which contributes to the reduction in the tropospheric ozone burden in the tropics. The associated re-partitioning of nitrogen between PAN, $\mathrm{HNO}_{3}$ and organic nitrates also results in a $\sim 5 \%$ increase in the loss of nitrogen by wet deposition. At a global scale there is a reduction in the oxidizing capacity of the model atmosphere which increases the atmospheric lifetimes of $\mathrm{CH}_{4}$ and CO by $\sim 1.5 \%$ and $\sim 4 \%$, respectively. Comparisons against a range of different measurements indicate that applying the 12 year average of Lathière et al. (2006) improves the performance of TM4_AMMA for 2006 in the tropics. By the use of sensitivity studies we show that the release of NO from soils in Africa accounts for between $\sim 2-45 \%$ of tropospheric ozone in the African troposphere, $\sim 10 \%$ in the upper troposphere and between $\sim 5-20 \%$ of the tropical tropo-
\end{abstract}

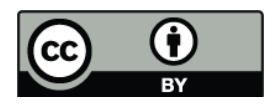

Correspondence to: J. E. Williams (williams@knmi.nl) spheric ozone column over the tropical Atlantic Ocean. The subsequent reduction in $\mathrm{OH}$ over the source regions allows enhanced transport of $\mathrm{CO}$ out of the region. For biogenic volatile organic $\mathrm{C} 1$ to $\mathrm{C} 3$ species released from Africa, the effects on tropical tropospheric ozone are rather limited, although this source contributes to the global burden of VOC by between $\sim 2-4 \%$ and has a large influence on the organic composition of the troposphere over the tropical Atlantic Ocean.

\section{Introduction}

Biogenic emissions of trace gas species from vegetation and soils are considered to be an important emission source that can significantly affect the composition of the troposphere for many tropical regions (e.g. Aghedo et al., 2007). Although isoprene is the most dominant biogenic species (Guenther et al., 2006) recent field measurements have shown that a diverse range of Biogenic Volatile Organic Compounds (BVOCs) are released at lower rates from a range of vegetation types (e.g. Villanueva-Fierro et al., 2004). Therefore, to be able to differentiate the contributions from anthropogenic and natural activity on tropospheric ozone in remote regions requires that accurate estimates related to the global fluxes of such BVOCs are available.

The most important biogenic emission for tropospheric ozone production is the direct emission of nitric oxide (NO) from recently wetted-soils. This is now widely recognized as being an important natural source of reactive nitrogen at remote locations in the tropics (e.g. Yienger and Levy, 1995).

Published by Copernicus Publications on behalf of the European Geosciences Union. 
The source strength is dependent on certain meteorological and geophysical variables such as recent precipitation history, soil type and temperature (Ludwig et al., 2001; Delon et al., 2009). The optimal combination of these parameters results in intense pulses of NO being emitted for short periods of time after any rainfall event (Davidson, 1992; Stewart et al., 2008). Such events are often followed by periods of relative inactivity where the emission of NO is much lower. This imposes a seasonal cycle on the emission between the dry and wet seasons, where biogenic $\mathrm{NO}_{\mathrm{x}}$ emissions exhibit only moderate inter-annual variability compared to biomass burning emissions (van der Werf et al., 2006; van der A et al., 2008). For sparsely populated regions such as Equatorial Africa, these emissions have the potential to influence the background levels of tropospheric ozone $\left(\mathrm{O}_{3}\right)$ and, thus, the atmospheric lifetimes of other important trace gas species such as carbon monoxide $(\mathrm{CO})$ and methane $\left(\mathrm{CH}_{4}\right)$ via perturbations in $[\mathrm{OH}]$, especially considering that a large fraction of the total global oxidation of such trace species occurs in the tropics.

Further information regarding both the scale and importance of such biogenic emissions has recently been forthcoming from the analysis of observations made by a host of earthorbiting satellites. For instance, Jaeglé et al. (2004) used nitrogen dioxide $\left(\mathrm{NO}_{2}\right)$ columns retrieved from the Global Ozone Monitoring Experiment (GOME), in tandem with independent fire observations, to investigate the spatial and seasonal variation of the release of NO from soils. They conclude that such soil emissions account for $\sim 40 \%$ of surface $\mathrm{NO}_{\mathrm{x}}$ in Africa, affecting $3 \times 10^{6} \mathrm{~km}^{2}$ of sub-Saharan Africa during the wet season. Another prominent example is the decadal trend analysis conducted by Van der A et al. (2008) using a composite of data from various satellite instruments, where they conclude that $\mathrm{NO}_{\mathrm{x}}$ emissions from soils are the dominant sources of nitrogen oxides in northern Africa (between $\sim 12-35^{\circ} \mathrm{N}$ ). Moreover, the maximum emissions occur in the summer months of each respective hemisphere, which is somewhat anti-correlated with the release of $\mathrm{NO}_{\mathrm{x}}$ from biomass burning events. For BVOCs the detection of surface concentrations from satellites is problematic due to the weak spectral absorption features exhibited by most compounds in the spectral windows typically used for such measurements and the relatively low concentrations (typically less than a nmol/mol). Although formaldehyde (HCHO) can be retrieved from such satellite observations (e.g. Palmer et al., 2003), the predominant fraction in remote regions is assumed to come from the oxidation of isoprene $\left(\mathrm{C}_{5} \mathrm{H}_{8}\right)$ rather than as a result of a direct biogenic emission.

The large surface area over which soil NO emissions are important means that any model used to investigate the composition of the troposphere in the tropics needs to include an accurate inventory. To date, the predominant emission inventory used in large scale global 3-D Chemistry Transport Models to account for the emissions of NO from soils is that provided by Yienger and Levy (1995), which results in a global estimate of $5.5 \mathrm{TgN} / \mathrm{year}$. This is somewhat less than the annual emission flux estimated by Jaegle et al. (2004) of $7.3 \mathrm{TgN} / y e a r$, which is more consistent with the inventory of Davidson and Kingerlee (1997) of $7.9 \mathrm{TgN} / \mathrm{year}$. One potential emission source commonly missing from inventories is that from agricultural fertilizer, which perturbs the emission of NO from soil depending on the frequency, the scale of application and the intensity of crop production. Although Yienger and Levy (1995) do implicitly account for some contribution from fertilizer in their inventory, there is currently no global database available to account for such contributions. For the biogenic VOCs there are only a few estimates currently available, which are widely used throughout the modeling community. For instance the release of biogenic $\mathrm{CO}$ is typically set equal to the values taken from Müller and Brasseur (1995), regardless of the emission inventory, whereas for the $\mathrm{C} 2$ compounds, such as ethane $\left(\mathrm{C}_{2} \mathrm{H}_{6}\right)$, the values of Müller (1992) are still commonly used.

A large source of error when calculating such global biogenic emission estimates occurs during the process of upscaling, which can be partly overcome by the use of more sophisticated biogeochemical models that include a dynamic description of vegetation distribution and growth. Such models account for an interactive calculation of vegetation distribution, plant biophysics, rate of growth, variations in leaf area index (LAI) and differences in vegetation type, depending on climatic conditions (e.g. Potter et al., 1996; Lathière et al., 2006), which all influence the magnitude and seasonality of regional biogenic emissions. More sophisticated interactive approaches have also become available (e.g. Ganzeveld et al., 2002) which update the algorithm of Yienger and Levy (1995) in order to account for the subscale chemical processes and mixing which occur under/through the tree canopy. By coupling other meteorological parameters such as precipitation rates into the calculation of the NO emissions, the inter-annual variability can be captured with more accuracy. Finally, Delon et al. (2007) have proposed a method based on a neural-network approach that reacts towards climatic variables on very short time-scales. They have recently coupled this to a meso-scale model for studying an event in Equatorial Africa observed during the West African Monsoon (WAM) as part of the African Monsoon Multidisciplinary Experiment (AMMA) (Delon et al., 2008; Stewart et al., 2008). This resulted in an increase in tropospheric $\mathrm{O}_{3}$ in the lowest few kilometers of the atmosphere compared to simulations using the inventory of Yienger and Levy (1995). For BVOCs a new set of estimates has recently become available for trace species such as $\mathrm{HCHO}$ and acetic acid $\left(\mathrm{CH}_{3} \mathrm{COOH}\right)$ (Lathière et al., 2006). Moreover, there are also corresponding estimates for isoprene and $\mathrm{NO}$, which ensures consistency with the method from which they are calculated.

In this study we investigate the influence of NO and BVOC emissions from soils and vegetation on the composition of the troposphere above Equatorial Africa, and surrounding 
regions affected by outflow, as part of the AMMA integrated research project (www.amma-eu.org; Redelsperger et al., 2006). For this purpose we use the recent inventory for biogenic emissions derived from multi-annual simulations between 1983 and 1995 from the vegetation model ORCHIDEE (Lathière et al., 2006) provided as part of the RETRO emission database (http://retro.enes.org). This is compared to the alternative estimates made available in the Present and future surface Emissions of atmospheric compounds (POET) database (Granier et al., 2005) to quantify the differences introduced into large-scale simulations of the global troposphere.

In Sect. 2 we give details concerning the model description and the sensitivity studies that have been performed. In Sect. 3 we will highlight the differences in the seasonality and magnitude between the two emission inventories for the African continent. In Sect. 4 we will show the effect of both soil $\mathrm{NO}_{\mathrm{x}}$ and other BVOCs on tropospheric ozone and the associated $\mathrm{NO}_{\mathrm{x}}$ reservoir species PAN and $\mathrm{HNO}_{3}$. In Sect. 5 we will then investigate the effect on the oxidative capacity of the global troposphere by analysis of the chemical budget terms. In Sect. 6 we will then assess the performance of the model against a suite of measurements taken in and around Equatorial Africa, and finally, we will present our conclusions in Sect. 7.

\section{Model description}

The global CTM used in this study is the TM4 model, which has recently participated in a host of multi-model intercomparison exercises (e.g. Van Noije et al., 2006; Stevenson et al., 2006). The model version is identical to that described in Van Noije et al. (2006) except that the uptake coefficient $\left(\gamma_{\mathrm{N}_{2} \mathrm{O}}\right)$ has been reduced to 0.02 in line with the recommendations of Evans and Jacob (2005) and the rate coefficient data has been updated according to the latest recommendations (Atkinson et al., 2006; Sander et al., 2006). Moreover, the photolysis rates have also been re-assessed using a chemical box-model, and the scaling parameters have been updated for the photolysis of the lumped organic nitrate species and methylglyoxal. The effects of this are discussed in depth in Williams and van Noije (2008). TM4 is driven by ECMWF meteorological data originally provided on 91 vertical layers but subsequently coarsened onto the TM4 resolution of 34 layers, where the vertical resolution is typically $1 \mathrm{~km}$ in the tropical upper troposphere/lowerstratosphere. The horizontal resolution used throughout was fixed at $3^{\circ}$ longitude $\times 2^{\circ}$ latitude. Since TM4 does not include stratospheric chemistry, the total overhead ozone column was nudged towards the monthly mean averages from the Ozone Monitoring Experiment (OMI) using the climatology of Fortuin and Kelder (1998) to define the stratospheric profile. In order to differentiate between this updated version of TM4 and those used in previous modeling studies (e.g. van
Noije et al., 2006), we subsequently refer to this version as TM4_AMMA.

For the anthropogenic emissions we adopt the sector segregated estimates for the year 2000 made available through the RETRO website (http://retro.enes.org). These are based on the TNO Emission Assessment Model (TEAM) and are segregated with respect to the sector from which the emission originates. The emissions from all sectors except transport are injected between $0-200 \mathrm{~m}$ above the ground. These are supplemented with inventories for $\mathrm{NH}_{3}$ and $\mathrm{SO}_{2}$ taken from the EDGAR-HYDE version 1.3 (Van Aardenne et al., 2001). For ship emissions we adopt the estimates from Endresen et al. (2003) and for aircraft emissions those from the AEROCOM project (Lee et al., 2002; Grewe et al., 2002). For road transport we introduce the emissions in the lowest model layer, for ships we split the emissions evenly between the lowest two layers and for aircraft we use the vertical distribution defined in Grewe et al. (2002). For biomass burning emissions we use the monthly aggregated estimates from the GFEDv2 database (van der Werf et al., 2006) and apply the injection heights given in Lavoué et al. (2000). These biomass burning emissions are injected at a fixed rate throughout each day of the month. For lightning $\mathrm{NO}_{\mathrm{x}}$ we apply the parameterization of Meijer et al. (2001) which gives a global lightning source of $\sim 5.9 \mathrm{TgN}$ for 2006 , which is slightly higher than the most likely range of $\sim 5 \mathrm{Tg}$, but well within the current uncertainty range (Schumann and Huntrieser, 2007). For all runs we do not include specific emissions for $\mathrm{CH}_{4}$, but impose a latitudinal gradient on the concentration for $\mathrm{CH}_{4}$ at the surface. It should be noted that non-eruptive volcanic $\mathrm{SO}_{2}$ emissions are taken from Andres and Kasgnoc (1998).

In order to investigate the influence of the different biogenic inventories we define a number of different experiments where we vary the biogenic emission fluxes applied in the model. For the BASE (baseline) simulation we use the biogenic emission files supplied from the POET project (Granier et al., 2005), which provide values for biogenic $\mathrm{NO}, \mathrm{CO}$, methanol $\left(\mathrm{CH}_{3} \mathrm{OH}\right)$, ethene $\left(\mathrm{C}_{2} \mathrm{H}_{4}\right), \mathrm{C}_{2} \mathrm{H}_{6}$, propane $\left(\mathrm{C}_{3} \mathrm{H}_{8}\right)$, propene $\left(\mathrm{C}_{3} \mathrm{H}_{6}\right)$, acetone $\left(\mathrm{CH}_{3} \mathrm{COCH}_{3}\right)$, isoprene and the monoterpenes, where all are applied globally. For the LATH simulation we use the 12 year average from between 1983-1995 as provided by Lathière et al. (2006). This replaces the emission fluxes for $\mathrm{NO}, \mathrm{CH}_{3} \mathrm{OH}$, acetone, isoprene and the monoterpenes compared to the BASE simulation and provides additional emission estimates for acetaldehyde $\left(\mathrm{CH}_{3} \mathrm{CHO}\right), \mathrm{CH}_{3} \mathrm{COOH}$, and $\mathrm{HCHO}$, where the emissions used for all the other BVOC species are identical to the BASE simulation. For isoprene we distribute the emissions equally between the lowest two model layers and impose a diurnal variation on the emission to account for the effects of sunlight and temperature. Again, the Lathière et al. (2006) emission estimates are applied globally.

The methodologies used for the derivation of the biogenic emission estimates in each emission inventory are somewhat 
species dependent. For NO, the POET inventory adopts the estimates made by Yienger and Levy (1995), which accounts for some contribution due to fertilizer, whilst the RETRO inventory excludes this anthropogenic contribution due to the lack of reliable data at a global scale (i.e. it is not implicitly included in the estimates of Lathière et al., 2006). Considering the rather modest use of fertilizer in Africa for crop production, and that only $\sim 1-10 \%$ of nitrogen contained in fertilizer is released as NO (Yienger and Levy, 1995), the bias introduced into the simulations is assumed to be small. For the BVOC emissions the parameterization of Guenther et al. (1995) is used in both cases, where the difference arises from the dynamical input variables which are supplied by the vegetation model ORCHIDEE for the Lathière et al. (2006) inventory, which privides some feedback regarding climatic changes, and that (e.g.) leaf aging is accounted for in the Lathière et al. (2006) inventory. For more details related to the processes which are included in the ORCHIDEE model the reader is referred to Krinner et al. (2005).

The TM4_AMMA model uses the modified CBM4 chemical mechanism of Houweling et al. (1998), which represents C2 and higher organics as a set of lumped organic species based on the reactivity of the characteristic functional groups. Table 1 shows how each of the biogenic species described above is introduced into TM4_AMMA and summarises the degree of commonality between each of these runs with respect to biogenic carbon emissions. The speciation into CBM lumped species was done according to the details given in Yarwood et al. (2005). Here explicit species are partitioned according to the functional groups which they include (e.g.) PAR for paraffinic bonds and OLE for olefinic bonds. A main difference between the inventories is that no ALD2, OLE or HCHO is introduced from biogenic sources in the BASE run.

For the two additional sensitivity studies we adopt the global emission inventories used for the LATH run and introduce the following modifications. To determine the influence of $\mathrm{NO}$ emitted from soil in Africa we perform a simulation where the soil NO flux is removed for the African Continent (hereafter referred to as NOSOIL). To investigate the cumulative effect of the BVOC's we perform a simulation where the biogenic emissions of organic compounds are removed for the African continent, except those for isoprene and the monoterpenes (hereafter referred to as NOBIO). The emission fluxes for these two species are so large that we feel it would be unrealistic to completely remove them and the effects of isoprene are not the focus of these studies. Such effects have been covered previously in the literature (e.g. von Kuhlmann et al., 2004) therefore we place the focus on the other biogenic carbon emissions available in the inventory, which are not included in many models.
Table 1. Details concerning the chemical speciation of the organic biogenic emissions used in both the BASE and LATH simulations. The emission flux for $\mathrm{CH}_{3} \mathrm{OH}$ is used to account for emissions of $\mathrm{CH}_{3} \mathrm{CH}_{2} \mathrm{OH}$, where the flux is set at $10 \%$ of the $\mathrm{CH}_{3} \mathrm{OH}$ emissions. For species with $(+)$ the same emission inventory is used in both simulations.

\begin{tabular}{|c|c|c|c|}
\hline $\begin{array}{l}\text { Organic } \\
\text { Species }\end{array}$ & BASE & LATH & $\begin{array}{l}\text { Speciation in } \\
\text { the modified } \\
\text { CBM4 mechanism }\end{array}$ \\
\hline $\mathrm{CO}^{+}$ & yes & yes & $\mathrm{CO}$ \\
\hline $\mathrm{HCHO}$ & no & yes & $\mathrm{HCHO}$ \\
\hline $\mathrm{CH}_{3} \mathrm{OH}$ & yes & yes & $0.1 * \mathrm{PAR}$ \\
\hline $\mathrm{C}_{2} \mathrm{H}_{4}$ & yes & yes & ETH \\
\hline $\mathrm{C}_{2} \mathrm{H}_{6}^{+}$ & yes & yes & $2 * \mathrm{PAR}$ \\
\hline $\mathrm{C}_{3} \mathrm{H}_{8}^{+}$ & yes & yes & $3 *$ PAR \\
\hline $\mathrm{C}_{3} \mathrm{H}_{6}^{+}$ & yes & yes & $\mathrm{PAR}+2 * \mathrm{OLE}$ \\
\hline $\mathrm{CH}_{3} \mathrm{CHO}$ & no & yes & ALD2 \\
\hline $\mathrm{HCOOH}$ & no & yes & N/A \\
\hline $\mathrm{CH}_{3} \mathrm{COOH}$ & no & yes & $0.5 * \mathrm{PAR}$ \\
\hline Acetone & yes & yes & $3 *$ PAR \\
\hline Isoprene & yes & yes & ISOP \\
\hline Monoterpenes & yes & yes & ISOP \\
\hline
\end{tabular}

\section{Differences in the emission inventories for Africa}

In this section we investigate the differences in the biogenic emission inventories for both the BASE and LATH runs. For this study we principally focus on Africa (defined here as between $20^{\circ} \mathrm{W}-40^{\circ} \mathrm{E}, 40^{\circ} \mathrm{S}-40^{\circ} \mathrm{N}$ ) and adopt four latitudinal zones in Africa similar to those defined in the AMMA Multimodel Intercomparison Project (AMMA-MIP, Williams et al., 2009), these being: Sahara $\left(20-40^{\circ} \mathrm{N}\right)$, Sahel $(10$ $\left.20^{\circ} \mathrm{N}\right)$, Guinea $\left(0-10^{\circ} \mathrm{N}\right)$ and southern Africa $\left(40^{\circ} \mathrm{S}-0^{\circ} \mathrm{N}\right)$. This corresponds to land surface areas of $8.59 \times 10^{6} \mathrm{~km}^{2}$, $6.55 \times 10^{6} \mathrm{~km}^{2}, 5.63 \times 10^{6} \mathrm{~km}^{2}$ and $8.32 \times 10^{6} \mathrm{~km}^{2}$, respectively.

Figures 1 to 3 show direct comparisons of the monthly emission fluxes for biogenic NO, isoprene and organic carbon, respectively, for all four latitudinal zones. It can be seen that for both the NO and BVOC monthly emissions the seasonal distribution differs markedly between the inventories. Table 2 compares the resulting annually integrated anthropogenic, biomass burning and biogenic emission totals for each latitudinal zone in order to quantify the importance of the biogenic emission for each zone. For biogenic emissions of NO most latitude zones exhibit a contribution that exceeds that from anthropogenic activity. The exception is the Sahara region, where the dry conditions and cities in the southern Mediterranean result in a higher contribution from anthropogenic emissions. Moreover, the differences in the annually integrated fluxes between the BASE simulation, which uses the Yienger and Levy (1995) estimates included in the POET 
Table 2. Emission totals for the contributions to $\mathrm{NO}_{\mathrm{x}}, \mathrm{CO}$, isoprene and organic carbon from (in listed order) anthropogenic activity, biomass burning and biogenic activity for each latitudinal zone. For the biogenic component integrated totals are shown for both the BASE and LATH simulations, respectively, along with resulting percentage difference for each of the regions. For biogenic CO the same inventory is used in both runs. For the NOSOIL simulations the emissions denoted with (\#) are removed and for the NOBIO simulation the emissions denoted with $\left(^{*}\right)$ are removed. Summing these segregated emission totals gives 6.91 (6.91) $\mathrm{TgN} \mathrm{yr}^{-1}, 250.15 \mathrm{TgCO}^{-1}, 112.07(137.62) \mathrm{TgC} \mathrm{yr}^{-1}$ (isoprene) and 20.34 (11.27) $\mathrm{TgC} \mathrm{yr}^{-1}$ (BVOCs), where the BASE sums are given in parenthesis except for CO.

\begin{tabular}{llrrrr}
\hline $\begin{array}{l}\text { Trace } \\
\text { species }\end{array}$ & Emission & $\begin{array}{r}\text { Sahara } \\
\left(20-40^{\circ} \mathrm{N}\right)\end{array}$ & $\begin{array}{r}\text { Sahel } \\
\left(10-20^{\circ} \mathrm{N}\right)\end{array}$ & $\begin{array}{r}\text { Guinea } \\
\left(0-10^{\circ} \mathrm{N}\right)\end{array}$ & $\begin{array}{r}\text { Southern Africa } \\
\left(40^{\circ} \mathrm{S}-0^{\circ} \mathrm{N}\right)\end{array}$ \\
\hline $\mathrm{NO}_{\mathrm{x}}$ & Anth & 1.12 & $1.13 \times 10^{-1}$ & $2.30 \times 10^{-1}$ & $6.96 \times 10^{-1}$ \\
$(\mathrm{TgN} / \mathrm{yr})$ & BB & $2.81 \times 10^{-3}$ & $2.40 \times 10^{-1}$ & 1.01 & 1.19 \\
& Bio (BASE) & $2.18 \times 10^{-1}$ & $6.12 \times 10^{-1}$ & $7.74 \times 10^{-1}$ & $7.02 \times 10^{-1}$ \\
& Bio (LATH) & $2.01 \times 10^{-1}(\#)$ & $5.75 \times 10^{-1}(\#)$ & $7.64 \times 10^{-1(\#)}$ & $7.64 \times 10^{-1(\#)}$ \\
& $\%$ diff Bio & $(-7.5 \%)$ & $(-6.3 \%)$ & $(-1.3 \%)$ & $(+8.0 \%)$ \\
$\mathrm{CO}$ & Anth & 13.83 & 14.90 & 23.10 & 18.46 \\
$(\mathrm{TgCO} / \mathrm{yr})$ & BB & $1.64 \times 10^{-1}$ & 13.77 & 65.37 & 70.43 \\
& Bio (ALL) & 3.09 & 4.43 & 10.59 & 12.02 \\
& $\%$ diff Bio & $(\mathrm{N} / \mathrm{A})$ & $(\mathrm{N} / \mathrm{A})$ & $(\mathrm{N} / \mathrm{A})$ & $(\mathrm{N} / \mathrm{A})$ \\
Isoprene & Bio (BASE) & 3.46 & 16.10 & 51.45 & 41.06 \\
$(\mathrm{TgC} / \mathrm{yr})$ & Bio (LATH) & 3.58 & 20.54 & 56.99 & 56.51 \\
& \%diff Bio & $(-3.4 \%)$ & $(-27.6 \%)$ & $(-9.7 \%)$ & $(-27.3 \%)$ \\
Organic & Anth & 2.48 & 1.07 & 1.97 & 1.40 \\
Carbon & BB & $4.24 \times 10^{-3}$ & $3.57 \times 10^{-1}$ & 1.87 & $7.83 \times 10^{-1}$ \\
$(\mathrm{TgC} / \mathrm{yr})$ & Bio (BASE) & $1.47 \times 10^{-1}$ & $1.46 \times 10^{-1}$ & $3.59 \times 10^{-1}$ & $6.86 \times 10^{-1}$ \\
& Bio (LATH) & $5.05 \times 10^{-1}(*)$ & $1.25^{(*)}$ & $4.84^{(*)}$ & $3.81^{(*)}$ \\
& $\%$ diff Bio & $(+343 \%)$ & $(+858 \%)$ & $(+1348 \%)$ & $(+556 \%)$ \\
\hline
\end{tabular}
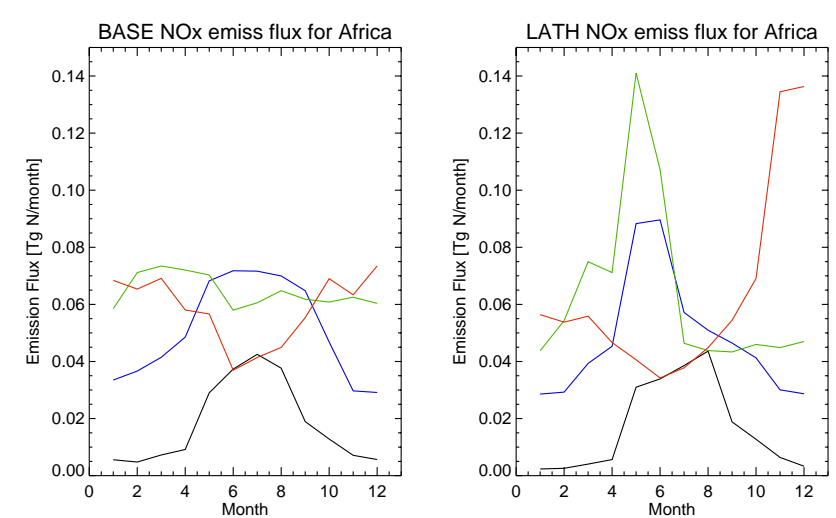

Fig. 1. A comparison of the monthly emission flux of NO from soils in $\mathrm{TgN}$ as provided in (a) the POET inventory (from Yienger and Levy, 1995) and (b) the RETRO inventory (from Lathiere et al., 2006). The key for the latitudinal regions is: (black) Saharan, (blue) Sahel, (green) Guinea and (red) southern Africa.

inventory, and the LATH simulation, which adopts the estimates from Lathière et al. (2006), are relatively small for all regions, although the seasonality is much larger in Lathière et al. (2006) as shown in Fig. 1. There are also differences with respect to longitude that are not highlighted by the latitudinal
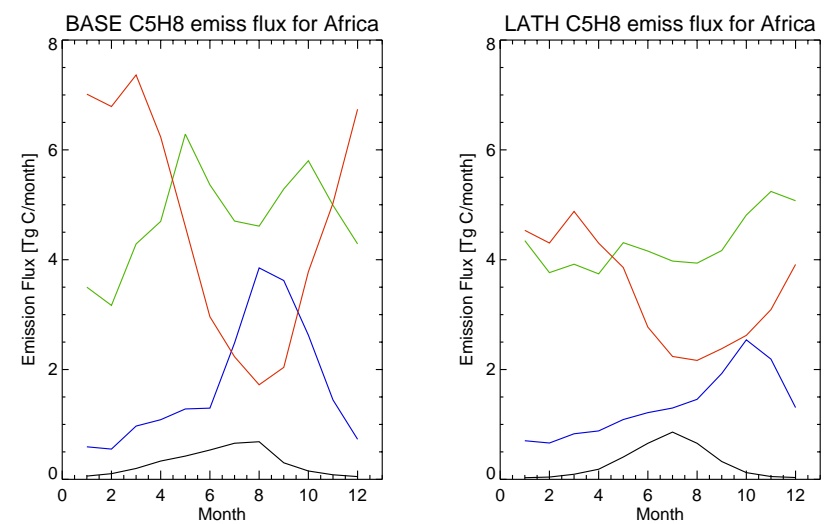

Fig. 2. A comparison of the monthly emission flux of Isoprene in $\mathrm{TgC}$ as provided in (a) the POET inventory and (b) by Lathiere et al. (2006). The key for the latitudinal regions is: (black) Saharan, (blue) Sahel, (green) Guinea and (red) southern Africa.

comparison. For instance, during February there is more surface $\mathrm{NO}_{\mathrm{x}}$ near the west coast of Africa around $10^{\circ} \mathrm{S}$ in the Lathière et al. (2006) inventory. Such differences will become apparent when performing a comparison of model output from the various simulations with ground measurements 

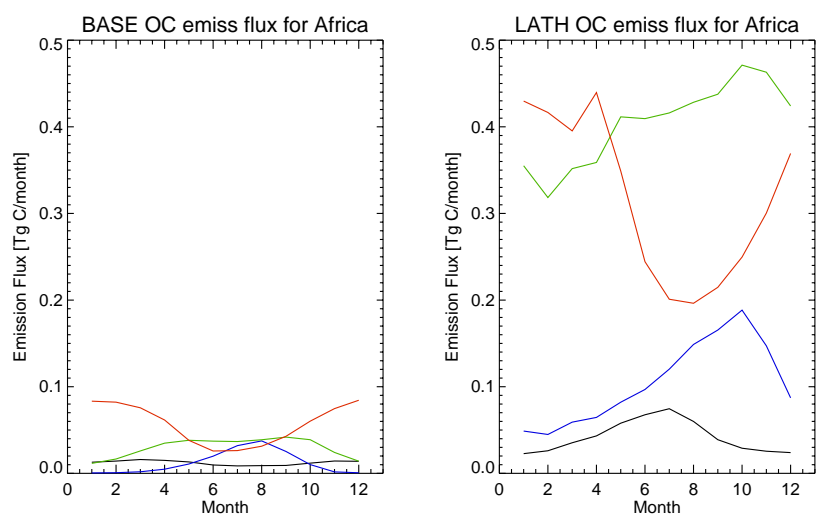

Fig. 3. A comparison of the monthly emission flux of organic carbon from vegetation in $\mathrm{TgC}$ as provided in (a) the POET inventory and (b) by Lathiere et al. (2006). The key for the latitudinal regions is: (black) Saharan, (blue) Sahel, (green) Guinea and (red) southern Africa.

(see Sect. 6). For CO, where the same biogenic inventory is used in both simulations, the contribution from biogenic activity is the lowest of all emission sources, although still not negligible, reaching $\sim 50 \%$ of the anthropogenic contribution for the Guinea region. For isoprene, the POET inventory has higher annual emissions for all regions, where the differences are especially large for the Sahel and southern Africa. This can be partially explained by considering the origin of the estimates in both inventories. In the POET inventory the estimates from Guenther et al., 1995 are employed, whereas in Lathière et al. (2006), although similar parameterizations are used, vegetative growth between 1983 and 1995 is accounted for due to both climatic change and increasing $\left[\mathrm{CO}_{2}\right]$ which alters the input variables used. However, the largest differences between the emission inventories are related to the other BVOCs, where differences of $>200 \%$ occur in the monthly fluxes, although in terms of total biogenic carbon this is somewhat negated by the increased isoprene emissions in the POET inventory from each region.

\section{The seasonal differences in tropospheric $\mathrm{O}_{3}$ and $\mathrm{NO}_{\mathrm{x}}$ over Africa}

\subsection{The effect of the different biogenic emission inventories}

Once emitted, $\mathrm{NO}$ is oxidized to $\mathrm{NO}_{2}$ via the reaction with $\mathrm{HO}_{2}, \mathrm{CH}_{3} \mathrm{O}_{2}$ or $\mathrm{O}_{3}$. This additional $\mathrm{NO}_{2}$ can then be either rapidly photolysed (producing $\mathrm{O}_{3}$ ) or react with reactive free-radical species such as $\mathrm{OH}, \mathrm{HO}_{2}$ or $\mathrm{CH}_{3} \mathrm{C}(\mathrm{O}) \mathrm{O}_{2}$ to form more stable reservoir species for reactive nitrogen, namely $\mathrm{HNO}_{3}, \mathrm{HNO}_{4}$ or PAN. A further nitrogen reservoir is included in TM4_AMMA in the form of a lumped organic nitrate (hereafter referred to as ORGNTR). However, for brevity, we exclude it from the subsequent comparisons shown in the figures below and simply make a few comments on the subsequent changes as a result of adopting the various inventories. Such reservoir species have longer atmospheric lifetimes than $\mathrm{NO}_{2}$ and, once formed, may be transported away from the main source regions by convective and advective transport processes. Upon decomposition, photolytic destruction or oxidation, these species may then re-release reactive nitrogen far away from the source regions. Moreover, during the wet season a certain fraction is removed via heterogeneous scavenging (e.g.) transfer of $\mathrm{HNO}_{3}$ and ORGNTR into cloud droplets/wet aerosol followed by wet deposition. The additional BVOC in the LATH inventory also alters the $\mathrm{HO}_{\mathrm{x}}$ budget by increasing the fraction of $\mathrm{OH}$ scavenged by organic trace species (see Sect. 5).

In order to investigate the differences in the distribution and resident concentration of tropospheric $\mathrm{O}_{3}$ and associated $\mathrm{NO}_{\mathrm{x}}$ reservoirs between each of the emission inventories used in this study we have defined a number of 2-D cross-sections which reflect the "zonality" of the African region similar to that used in AMMA-MIP project (Williams et al., 2009). A subset of the chemical species is averaged over a $9^{\circ}$ longitude range between $12-21^{\circ} \mathrm{E}$ for a latitude range of $20^{\circ} \mathrm{S}$ to $40^{\circ} \mathrm{N}$, which is chosen as it encompasses a wide range of land types. The values have been written out by TM4_AMMA every three hours for all vertical levels which allows various comparisons to be performed offline for the whole of the region using different averaging frequencies (i.e.) daily, weekly or monthly. Here we wish to look at the seasonal behaviour and therefore use seasonal averages of the data.

Figure 4 shows the distribution of tropospheric $\mathrm{O}_{3}$ as a seasonal mean calculated from the 2-D cross section for the LATH simulation. Plots are shown for all seasons, namely December-January-February (DJF), MarchApril-May (MAM), June-July-August (JJA) and SeptemberOctober-November (SON) of 2006, along with the corresponding percentage differences when compared to the BASE simulation. For the lower troposphere the highest $\left[\mathrm{O}_{3}\right]$ occurs between $\pm 10^{\circ}$ latitude during the seasons DJF and JJA, where there is a shift from the Northern Hemisphere (hereafter referred to as $\mathrm{NH}$ ) to the Southern Hemisphere (hereafter referred to as $\mathrm{SH}$ ) in the course of the year. The maximum $\left[\mathrm{O}_{3}\right]$ values of $\sim 100 \mathrm{ppbv}$ occur near regions influenced by intense biomass burning activity. Imposed on this are the effects of the regional differences in the soil $\mathrm{NO}_{\mathrm{x}}$ emission inventories as shown in Fig. 1, with maximal differences occurring near the Equator during seasons MAM and SON (cf. Fig. 4d and h). Moreover, for periods where there are similar regional biogenic $\mathrm{NO}_{\mathrm{x}}$ emissions (e.g. southern Africa during SON) there is also a signature present from the higher isoprene emissions present in the BASE run. In general, the LATH run has a lower tropospheric ozone burden as a result of a re-distribution in the speciation of reactive nitrogen between reservoir compounds, which we discuss 

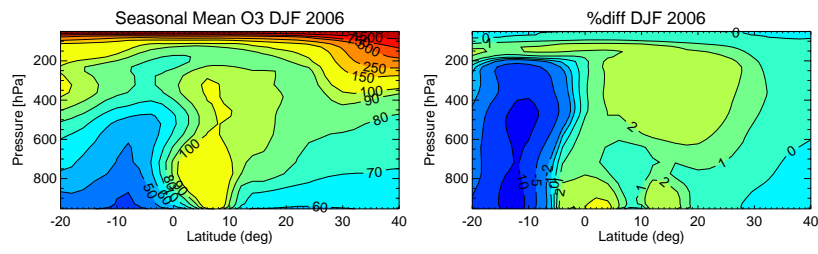

Seasonal Mean O3 MAM 2006
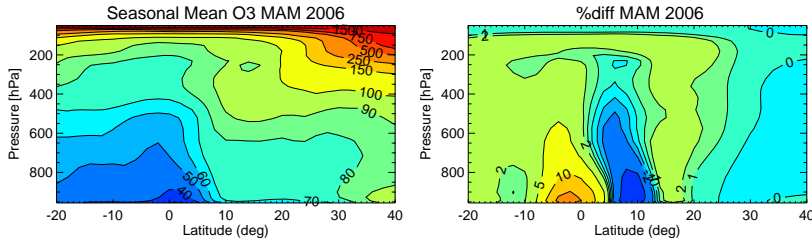

Seasonal Mean O3 JJA 2006
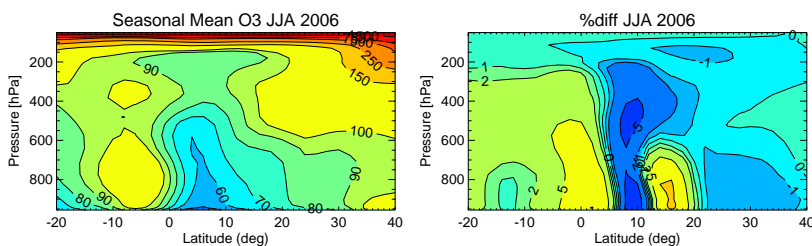

Seasonal Mean O3 SON 2006
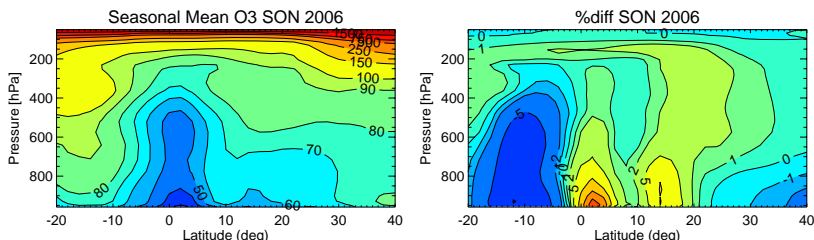

Fig. 4. A comparison of the seasonal means of tropospheric ozone in ppbv as averaged between $12-21^{\circ} \mathrm{E}$ for (a) DJF, (b) MAM, (c) JJA and (d) SON. The corresponding percentage change between the BASE and LATH simulations is shown for each season, where the difference shown is from (LATH-BASE)/BASE $\times 100 \%$.

in more detail below, where a budget analysis is also presented in Sect. 5. These decreases in tropospheric $\left[\mathrm{O}_{3}\right]$ extend out over the tropical Atlantic Ocean (not shown). This induces changes in the tropical tropospheric ozone column (TTOC) simulated in the model, which is defined as the integrated column below $200 \mathrm{hPa}$ as used in Valks et al. (2003). Moreover, a signature of the enhanced seasonality present in the soil $\mathrm{NO}_{\mathrm{x}}$ emissions of Lathière et al. (2006) can also be seen in the differences in the TTOC as far as South America (e.g.) increases of $\sim 10 \%$ occur for JJA between $0-20^{\circ} \mathrm{N}$ (not shown). This has the potential to make improvements to previous comparisons of the TTOC between 3-D CTM's and satellites, such as those presented in Peters et al. (2002) and Valks et al. (2003).

Figure 5 shows the corresponding figure for PAN, where maximal [PAN] occurs near regions of intense biomass burning activity as a result of the enhanced $\mathrm{NO}_{\mathrm{x}}$ emissions reacting with isoprene oxidation products, notably aldehydes. This explains why the highest [PAN] generally occurs between $10^{\circ} \mathrm{S}-10^{\circ} \mathrm{N}$ over densely forested regions and the lowest [PAN] (shown as blue areas in Fig. 5) occurs over the Sahel. The shift in the seasonality in the soil $\mathrm{NO}_{\mathrm{x}}$ emissions between the different emission inventories results in a higher
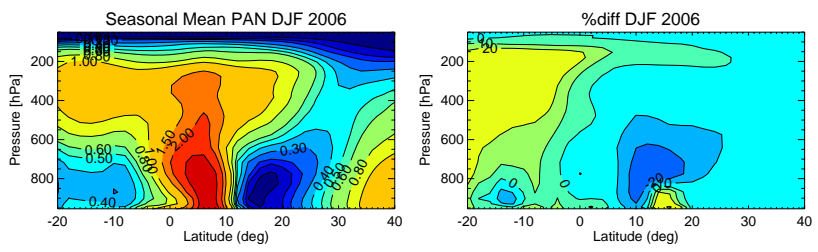

Seasonal Mean PAN MAM 2006
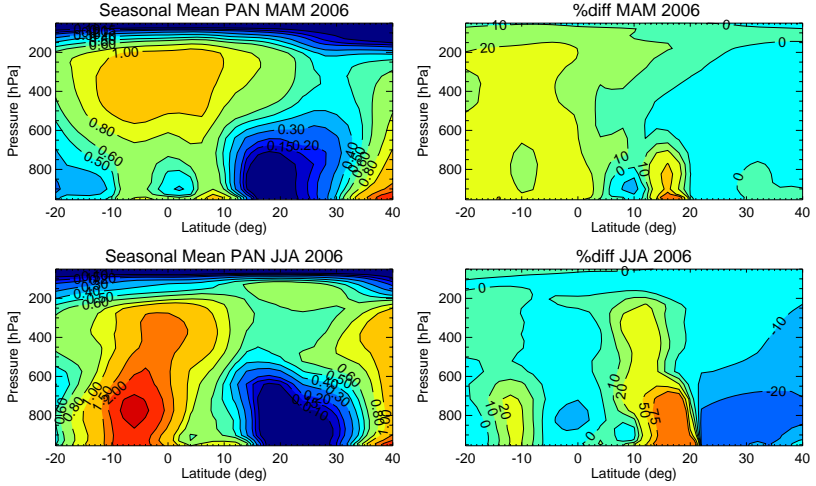

Seasonal Mean PAN SON 2006
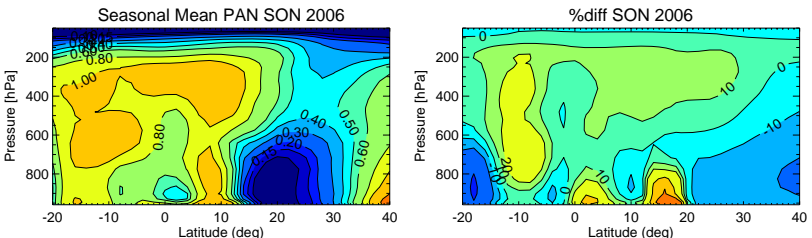

Fig. 5. A comparison of the seasonal means of PAN in ppbv as averaged between $12-21^{\circ} \mathrm{E}$ for (a) DJF, (b) MAM, (c) JJA and (d) SON. Similar percentage differences are shown as for Fig. 4.

fraction of the reactive nitrogen becoming sequestrated into PAN. Once formed, a significant fraction is subsequently transported via convective mixing throughout the entire troposphere, which ultimately dissociates releasing $\mathrm{NO}_{2}$. Comparing the differences between the simulations shows that for the Guinea region there are generally increases in [PAN] in the LATH run throughout the year, resulting in increases of $\sim 10-20 \%$ in the troposphere of the tropical Atlantic Ocean and a corresponding decrease in $\left[\mathrm{NO}_{\mathrm{x}}\right]$ by a few percent (not shown).

Finally, Fig. 6 shows the corresponding plot for $\mathrm{HNO}_{3}$, which is the most abundant $\mathrm{NO}_{\mathrm{x}}$ reservoir in the model with a burden that is $\sim 5$ times that of the other nitrogen reservoirs in the tropics (see Sect. 5). The formation of $\mathrm{HNO}_{3}$ is linked to the photolysis of $\mathrm{O}_{3}$, which explains the strong similarities that occur between the increases shown in Figs. 4 and 6 . Such a dependency can also be seen as a seasonal cycle when analyzing ground based measurements, as we show later in Sect. 6. The highest $\left[\mathrm{HNO}_{3}\right]$ values again occur near the regions affected by biomass burning emissions, where maximal concentrations of between $8-10$ ppbv occur. Comparing the corresponding seasonal distribution of [PAN] it can be seen that, when integrating along the transect, more reactive nitrogen is stored in the form of $\mathrm{HNO}_{3}$ as a result of this enhanced production of $\mathrm{HNO}_{3}$ in the lower troposphere. 

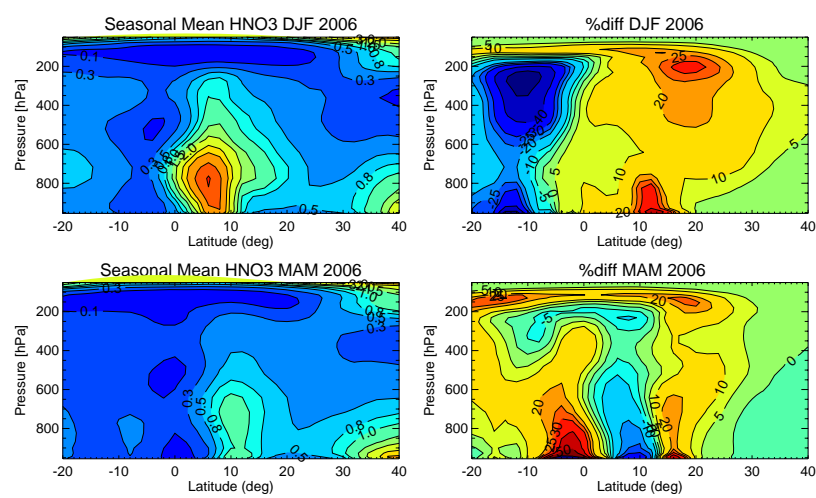

Seasonal Mean HNO3 JJA 2006
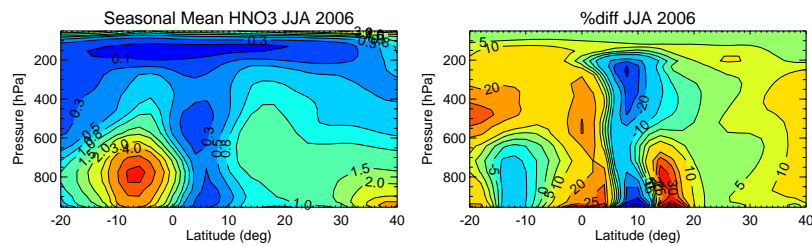

Seasonal Mean HNO3 SON 2006
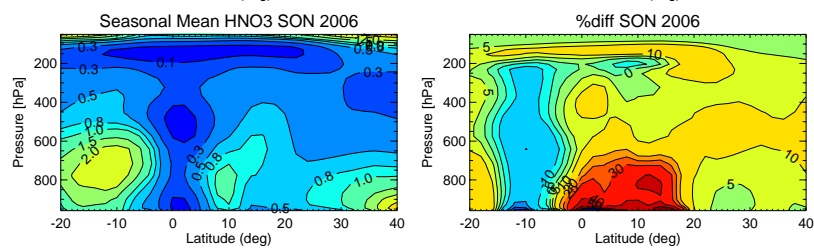

Fig. 6. A comparison of the seasonal means of $\mathrm{HNO}_{3}$ in ppbv as averaged between $12-21^{\circ} \mathrm{E}$ for (a) DJF, (b) MAM, (c) JJA and (d) SON. Similar percentage differences are shown as for Fig. 4.

This increases the loss of nitrogen via wet deposition due to the higher wet scavenging efficiency of $\mathrm{HNO}_{3}$. Moreover, this finding holds for most chemical mechanisms that include explicit $\mathrm{NO}_{\mathrm{x}}$ chemistry involving these two main nitrogen reservoir species.

The final nitrogen reservoir included in the chemical scheme is the ORGNTR species, which is predominantly formed by the reaction of $\mathrm{NO}$ with the $\mathrm{XO} 2 \mathrm{~N}$ alkylnitrate operator included in the modified CBM4 mechanism (Houweling et al., 1998). The main source of the XO2N operator is the oxidation of either isoprene or the lumped organic species, PAR, by $\mathrm{OH}$. Here the additional emissions of BVOC in the LATH run increase the annual net production of $\mathrm{XO} 2 \mathrm{~N}$ by $\sim 60 \%$ in the tropics, resulting in an annual increase in [ORGNTR] by $\sim 20 \%$. The atmospheric lifetime of ORGNTR is comparable to that of PAN allowing it to be transported outside of the main source regions, where increases of $\sim 10 \%$ occur over the tropical Atlantic Ocean.

\subsection{The effect of Soil $\mathrm{NO}_{\mathrm{x}}$}

Figure 7 shows the effect of removing the biogenic emission of NO from soils in Africa on tropospheric ozone for the 2D cross section (corresponding with Fig. 4) when compared with the LATH simulation. The highest biogenic NO emissions occur between $20^{\circ} \mathrm{S}-20^{\circ} \mathrm{N}$ (see Fig. 1), where $\sim 2-$
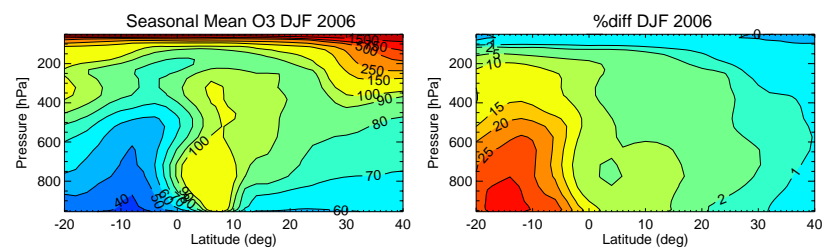

Seasonal Mean O3 MAM 2006
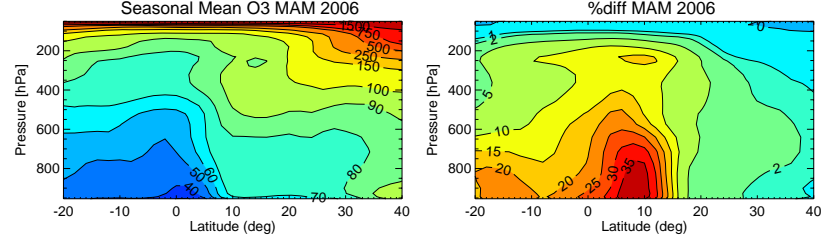

Seasonal Mean O3 JJA 2006
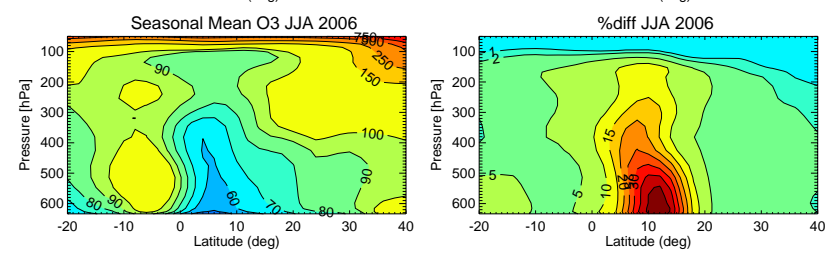

Seasonal Mean O3 SON 2006
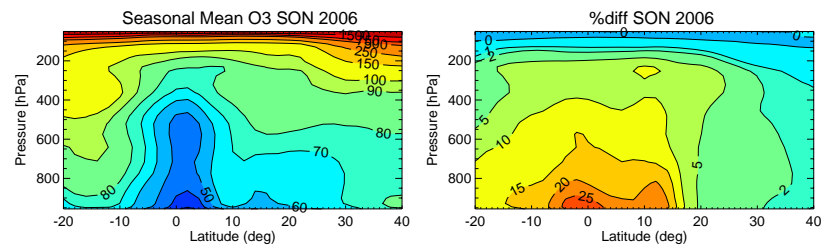

Fig. 7. A comparison of the seasonal means of tropospheric ozone in ppbv between the BASE and NOSOIL simulation as averaged between $12-21^{\circ} \mathrm{E}$ for (a) DJF, (b) MAM, (c) JJA and (d) SON. This comparison shows the influence of biogenic soil $\mathrm{NO}_{\mathrm{x}}$ on the tropospheric ozone burden over Africa. The corresponding percentage change between the LATH and NOSOIL simulations is shown for each season, where the difference shown is from (LATHNOSOIL)/LATH $\times 100 \%$.

$45 \%$ of tropospheric $\mathrm{O}_{3}$ below $200 \mathrm{hPa}$ is formed from the $\mathrm{NO}$ emitted from soils. However, the latitude at which the largest seasonal difference occurs does not strictly follow the seasonal distribution shown in Fig. 1 due to the variation in the regional contribution to $\mathrm{NO}_{\mathrm{x}}$ from biomass burning. The reduction in $\left[\mathrm{O}_{3}\right]$ due to the absence of soil $\mathrm{NO}$ emissions severely depletes $[\mathrm{OH}]$ by up to $\sim 60 \%$ at the surface, which significantly reduces the oxidizing capacity of the tropical troposphere (see Sect. 5). Again, the maxima in the seasonal differences in $[\mathrm{OH}]$ occur at similar locations as the maxima in the seasonal differences in $\left[\mathrm{O}_{3}\right]$. For $[\mathrm{PAN}]$ and $\left[\mathrm{HNO}_{3}\right]$ there are also significant reductions, with differences of up to $\sim 70 \%$ for both across the entire latitude range (not shown). This subsequently dampens the amount of reactive nitrogen reaching the UT thus decreasing the in situ formation of $\mathrm{O}_{3}$ in the UT by $\sim 5-7 \%$. A negative feedback mechanism exists in the sense that the reduction in [PAN] is in part due to the suppressed isoprene oxidation due to the lower $[\mathrm{OH}]$. This provides a marginal offset to the reduction in $\left[\mathrm{O}_{3}\right]$ due to lower isoprene by reducing the fraction of reactive nitrogen partitioned in PAN. 


\subsection{The effect of BVOCs}

Comparing the NOBIO simulation with the LATH simulation reveals that the effect on all three nitrogen reservoirs is rather minimal for the chosen latitudinal transect (not shown) (e.g.) for tropospheric $\mathrm{O}_{3}$ there are changes of $\pm 1 \%$. However, the additional BVOC loading in the LATH run results in a reduction in $[\mathrm{OH}]$ of $\sim 5 \%$ throughout the troposphere, resulting in similar differences in $\left[\mathrm{HNO}_{3}\right]$ (although this is dependent on the season). The reduction in the biogenic emission of ALD2 and PAR causes a reduction in both PAN and ORGNTR due the perturbations introduced for the radical pre-cursors of both species. The westerly transport of BVOCs out of the region results in large decreases in the VOC concentrations in the troposphere over the tropical Atlantic Ocean ( $\sim 20-50 \%$ ALD2 and PAR, $\sim 5 \%$ OLE). Therefore, although the effects of biogenic VOCs on tropospheric $\mathrm{O}_{3}$ formation are rather small compared to the influence of biogenic NO, a strong contribution is made to carbon loading in the Atlantic region as discussed in Sect. 5. It should also be noted that the emission of species such as $\mathrm{CH}_{3} \mathrm{OH}$ are not included in this study.

\section{Effect on the chemical budgets of tropospheric $\mathrm{O}_{3}$ and nitrogen reservoirs}

In this section we examine how the chemical budget for tropospheric $\mathrm{O}_{3}$ differs between the sensitivity studies and interpret the changes in the oxidation capacity of the atmosphere by examining the changes in the oxidation of both $\mathrm{CH}_{4}$ and $\mathrm{CO}$. In addition, we also quantify the differences in the partitioning of reactive nitrogen between the three most important reservoirs in the modified CBM4 mechanism discussed in Sect. 4. For this purpose we define the tropics as being the latitude band from $34^{\circ} \mathrm{S}-34^{\circ} \mathrm{N}$ in order to limit the influence from southern Europe and to include the southern coast of Africa. The budget analysis is calculated for all longitudes between $180^{\circ} \mathrm{W}-180^{\circ} \mathrm{E}$ in order to account for the differences in the chemical processes which occur in regions affected by advection of trace species and chemical pre-cursors out of Africa, and that each biogenic inventory was applied globally during the simulations. For the global budgets we adopt a methodology similar to that used in the multi-model intercomparison for large-scale 3-D CTM's performed by Stevenson et al. (2006). In our calculation we define the chemical production as the sum of the reactions of $\mathrm{NO}+\mathrm{HO}_{2}, \mathrm{NO}+\mathrm{CH}_{3} \mathrm{O}_{2}$ and $\mathrm{NO}+\mathrm{XO}_{2}$ (a lumped peroxy species), which are the main reactions that convert $\mathrm{NO}$ into $\mathrm{NO}_{2}$. For the chemical destruction we account for the loss of $\mathrm{O}_{3}$ by photolysis, $\mathrm{OH}, \mathrm{HO}_{2}, \mathrm{C}_{2} \mathrm{H}_{4}$, olefins and isoprene. The stratosphere-troposphere component is calculated from the difference of the production and destruction terms whilst accounting for the dry deposition component. For the effects on the oxidative capacity of the troposphere given in
Table 5 the procedure is identical to that used in Shindell et al. (2006).

Table 3 lists the chemical production and destruction terms for tropospheric $\mathrm{O}_{3}$ in the tropical troposphere integrated over the entire year. The corresponding changes with respect to the global burden and tropospheric lifetime of $\mathrm{O}_{3}\left(\tau_{\mathrm{O}_{3}}\right)$ are given in Table 4. Comparing the chemical terms for production and destruction in Table 3 for both the BASE and LATH simulations shows that the BASE simulation is more chemically active resulting in a higher tropical $\mathrm{O}_{3}$ burden, although $\tau_{\mathrm{O}_{3}}$ remains relatively unchanged. This increase in the production of $\mathrm{O}_{3}$ in the BASE simulation is due to a lower fraction of the reactive nitrogen being sequestrated into longerlived reservoir species (i.e. PAN, $\mathrm{HNO}_{3}$ ) when compared to the LATH simulation, as shown in Sect. 4. This results in a $\sim 5 \%$ increase in both the wet and dry deposition terms of $\mathrm{HNO}_{3}$ for the tropics in the LATH simulation, where the annual biogenic $\mathrm{NO}_{\mathrm{x}}$ emission is approximately equal between both emission inventories (see Table 1).

In the NOSOIL simulation there is a $\sim 5 \%$ reduction in the production of $\mathrm{O}_{3}$ in the tropics, which subsequently reduces the $\mathrm{O}_{3}$ burden in the tropics by $\sim 2 \%$. This translates into a $\sim 3.5 \%$ reduction in the global production of $\mathrm{O}_{3}$ due to the relative importance of the tropics towards global $\mathrm{O}_{3}$ chemistry (with a $\sim 1.6 \%$ reduction in the annually integrated global burden). This is smaller than the $\sim 5 \%$ contribution found in the study of Aghedo et al. (2007) for a multiannual simulation conducted between 1997-2002 using the ECHAM5-MOZ model adopting different emission inventories. In the NOBIO simulation only small differences in tropospheric $\mathrm{O}_{3}$ are introduced when compared to the LATH simulation, thus the direct emissions of C1-C3 organic compounds (e.g. $\mathrm{CO}$ and $\mathrm{HCHO}$ ) from Africa has a minimal effect on the regional $\mathrm{O}_{3}$ budget. However, it is most likely that the total biogenic carbon flux for $\mathrm{C} 1-\mathrm{C} 3$ species should be higher to account for the large number of species missing from the emission inventories (see discussion concerning $\mathrm{CH}_{3} \mathrm{OH}$ below).

The two most dominant sink reactions for $\mathrm{OH}$ in the troposphere involve the oxidation of $\mathrm{CH}_{4}$ and $\mathrm{CO}$, which are both abundant trace gas species with relatively long lifetimes. Moreover, in the troposphere their depletion is almost exclusively limited to the reaction with $\mathrm{OH}$, meaning that they act as a valid diagnostic for the integrated changes associated with the $\mathrm{HO}_{\mathrm{x}}$ budget and the rate at which they are depleted can be used to detect changes in the oxidative capacity of the global troposphere. Comparing the total global destruction of $\mathrm{CH}_{4}$ between the BASE and LATH simulations shows that $\sim 2 \%$ less $\mathrm{CH}_{4}$ is oxidized during 2006 in the LATH run as a result of suppressed $[\mathrm{OH}]$, which translates as an increase in the tropospheric lifetime of $\mathrm{CH}_{4}\left(\tau_{\mathrm{CH}_{4}}\right)$ by 0.15 years $(\sim 1.5 \%)$. For $\mathrm{CO}$ the corresponding increase in the tropospheric lifetime $\left(\tau_{\mathrm{CO}}\right)$ is a few days $(\sim 4 \%)$. For the NOSOIL simulation there is a further decrease in the rate at which $\mathrm{CH}_{4}$ and $\mathrm{CO}$ are oxidized compared to the LATH 
Table 3. The changes in the budgets and burdens for tropospheric ozone in the tropical region between $34^{\circ} \mathrm{S}-34^{\circ} \mathrm{N}$ and $180^{\circ} \mathrm{W}-180^{\circ} \mathrm{E}$ from the four simulations used in this study as integrated for 2006. The methodology is similar to that described in the multi-model intercomparison of Stevenson et al. (2006), where the troposphere is all grid cells with $\left[\mathrm{O}_{3}\right]<150 \mathrm{ppbv}$. The mean annual stratosphere-troposphere exchange equals $\sim 295 \pm 2 \mathrm{Tg} \mathrm{O}_{3} \mathrm{yr}^{-1}$.

\begin{tabular}{lrrrrr}
\hline & $\begin{array}{r}\text { Chemical } \mathrm{O}_{3} \\
\text { production } \\
\left(\mathrm{Tg} \mathrm{O}_{3} \mathrm{rr}^{-1}\right)\end{array}$ & $\begin{array}{r}\mathrm{Chemical}_{3} \\
\text { destruction } \\
\left(\mathrm{Tg} \mathrm{O}_{3} \mathrm{yr}^{-1}\right)\end{array}$ & $\begin{array}{r}\text { Dry } \\
\left(\mathrm{Tg} \mathrm{O}_{3} \mathrm{yr}^{-1}\right)\end{array}$ & $\begin{array}{r}\tau_{\mathrm{O}_{3}} \\
(\text { days })\end{array}$ & $\begin{array}{r}\text { Tropo } \\
\text { Burden } \\
(\mathrm{Tg})\end{array}$ \\
\hline BASE & 3137 & 3050 & 380 & 21.1 & 176 \\
LATH & 3099 & 3011 & 382 & 21.0 & 173 \\
NOSOIL & 2961 & 2900 & 361 & 21.4 & 170 \\
NOBIO & 3102 & 3012 & 381 & 21.1 & 174 \\
\hline
\end{tabular}

Table 4. The changes in the global budgets and burdens for tropospheric ozone from the four simulations used in this study as integrated for 2006. The methodology is taken from the multi-model intercomparison of Stevenson et al. (2006), where the troposphere is all grid cells with $\left[\mathrm{O}_{3}\right]<150 \mathrm{ppbv}$. The annual stratosphere-troposphere exchange is equal to $\sim 493 \mathrm{Tg} \mathrm{O}_{3} \mathrm{yr}^{-1}$ for all simulations.

\begin{tabular}{lrrrrr}
\hline & $\begin{array}{r}\text { Chemical } \mathrm{O}_{3} \\
\text { production } \\
\left(\mathrm{Tg} \mathrm{O}_{3} \mathrm{yr}^{-1}\right)\end{array}$ & $\begin{array}{r}\mathrm{Chemical} \mathrm{O}_{3} \\
\text { destruction } \\
\left(\mathrm{Tg} \mathrm{O}_{3} \mathrm{yr}^{-1}\right)\end{array}$ & $\begin{array}{r}\text { Dry } \\
\text { Deposition } \\
\left(\mathrm{Tg} \mathrm{O}_{3} \mathrm{yr}^{-1}\right)\end{array}$ & $\begin{array}{r}\tau_{\mathrm{O}_{3}} \\
(\text { days })\end{array}$ & $\begin{array}{r}\text { Tropo } \\
\text { Burden } \\
(\mathrm{Tg})\end{array}$ \\
\hline BASE & 4330 & 4160 & 662 & 23.8 & 315 \\
LATH & 4294 & 4122 & 664 & 23.8 & 312 \\
NOSOIL & 4143 & 3394 & 642 & 24.2 & 307 \\
NOBIO & 4292 & 4121 & 663 & 23.8 & 312 \\
\hline
\end{tabular}

Table 5. The integrated annual changes in the integrated global budgets, lifetimes and burdens for tropospheric $\mathrm{CH}_{4}$ and $\mathrm{CO}$ from the four simulations used in this study. The methodology is taken from the multi-model intercomparison of Stevenson et al. (2006), where the troposphere is all grid cells with $\left[\mathrm{O}_{3}\right]<150 \mathrm{ppbv}$.

\begin{tabular}{lrrrrr}
\hline Simulation & $\begin{array}{r}\mathrm{OH}+\mathrm{CH}_{4} \\
\text { destruction } \\
\left(\mathrm{Tg} \mathrm{CH}_{4} \mathrm{yr}^{-1}\right)\end{array}$ & $\begin{array}{r}\text { Tropospheric } \\
\mathrm{CH}_{4} \text { burden } \\
\left(\mathrm{Tg} \mathrm{CH}_{4}\right)\end{array}$ & $\begin{array}{r}{ }_{\mathrm{C}_{\mathrm{CH}}} \\
(\text { Years })\end{array}$ & $\begin{array}{r}\text { Tropo CO } \\
\text { burden } \\
(\mathrm{Tg} \mathrm{CO})\end{array}$ & $\begin{array}{r}{ }_{\mathrm{C}} \mathrm{CO} \\
(\text { Months })\end{array}$ \\
\hline BASE & 474 & 4271 & 9.15 & 340 & 1.81 \\
LATH & 465 & 4273 & 9.31 & 346 & 1.88 \\
NOSOIL & 449 & 4274 & 9.61 & 354 & 1.96 \\
NOBIO & 472 & 4273 & 9.20 & 337 & 1.86 \\
\hline
\end{tabular}

simulation due to suppressed $[\mathrm{OH}]$, in line with the decreases in tropospheric $\mathrm{O}_{3}$ discussed in Sect. 4. For $\mathrm{CO}$ the fraction which can be transported away from the main sources regions increases as a result of the further increase in $\tau_{\mathrm{CO}}$, where $\sim 50 \%$ of $\mathrm{CO}$ released globally from biomass burning originates in Africa (Jain, 2007). Previous studies have shown that $\mathrm{CO}$ from Africa can be transported over significant distances throughout the SH (e.g. Edwards et al., 2006). To quantify the influence of soil $\mathrm{NO}_{\mathrm{x}}$ on the transport of $\mathrm{CO}$ out of Africa we utilise another feature of the CTM experiments, which was the inclusion of a set of tagged tracers for $\mathrm{CO}$. For each of the four regions defined in Sect. 3 we in- cluded a chemically active tracer whose concentration was set equal to the cumulative emission of $\mathrm{CO}$ from biogenic, anthropogenic and biomass burning sources. Comparing the tropospheric burdens for the tagged $\mathrm{CO}$ tracers between the LATH and NOSOIL simulations shows that the global burden increases by between $6-10 \%$. Therefore, for years where there is little rainfall, and thus suppressed soil $\mathrm{NO}_{\mathrm{x}}$, and a corresponding increase in the incidence of wildfires, the $\mathrm{CO}$ which is released from biomass burning activity in Africa has a significantly longer lifetime.

For the NOBIO simulation there is only a marginal increase in the chemical reactivity when compared to the 
Table 6. The changes to the global and tropical tropospheric burdens for the three main reservoir species that contain reactive nitrogen oxides, isoprene and other BVOCs to which the additional emissions from the Lathiere et al. (2006) inventory contribute. All budget terms are given in either $\mathrm{TgN} \mathrm{yr}^{-1}$ or $\mathrm{TgC} \mathrm{yr}^{-1}$, with the tropical burdens being shown in paranthesis.

\begin{tabular}{lrrrr}
\hline & BASE & LATH & NOSOIL & NOBIO \\
\hline HNO $_{3}$ & $0.660(0.505)$ & $0.657(0.502)$ & $0.656(0.502)$ & $0.657(0.502)$ \\
PAN & $0.191(0.101)$ & $0.203(0.099)$ & $0.199(0.095)$ & $0.201(0.097)$ \\
ORGNTR & $0.183(0.134)$ & $0.207(0.147)$ & $0.198(0.139)$ & $0.202(0.143)$ \\
ISOP & $0.431(0.403)$ & $0.418(0.376)$ & $0.455(0.413)$ & $0.418(0.375)$ \\
HCHO & $0.349(0.279)$ & $0.339(0.263)$ & $0.335(0.260)$ & $0.337(0.262)$ \\
PAR & $3.320(0.970)$ & $4.780(1.719)$ & $4.883(1.803)$ & $4.603(1.568)$ \\
ALD2 & $0.327(0.173)$ & $0.349(0.170)$ & $0.341(0.163)$ & $0.344(0.166)$ \\
OLE & $0.313(0.172)$ & $0.332(0.222)$ & $0.344(0.233)$ & $0.323(0.213)$ \\
\hline
\end{tabular}

LATH simulation, although BVOCs from Africa are important for the organic carbon loading of the tropical Atlantic. Comparing the tagged tracer global burdens for $\mathrm{CO}$ shows that there are reductions of $\sim 15 \%$ as a result of removing the biogenic emission of $\mathrm{CO}$. This leads to a reduction of $\sim 4.4 \mathrm{Tg} \mathrm{CO}$ in the global troposphere, which is $\sim 1.5 \%$ of the total global burden for CO in the LATH simulation. Moreover, this reduces $\tau_{\mathrm{CH}_{4}}$ by $\sim 1.2 \%$ compared to the LATH simulation. Two additional emission fluxes are provided in the emission inventory of Lathière et al. (2006) which were not included in this experiment, these being for $\mathrm{HCOOH}$ and $\mathrm{CH}_{3} \mathrm{OH}$. Both $\mathrm{HCOOH}$ and $\mathrm{CH}_{3} \mathrm{OH}$ are fairly soluble and thus undergo some loss by wet deposition, although for $\mathrm{CH}_{3} \mathrm{OH}$ the global flux is estimated to be between 123-343 $\mathrm{CH}_{3} \mathrm{OH} \mathrm{Tg} \mathrm{yr}^{-1}$ (Millet et al., 2008), with a large fraction coming from biogenic and oceanic sources. If included in the modified CBM4 mechanism $\mathrm{CH}_{3} \mathrm{OH}$ would be oxidized by $\mathrm{OH}$ and produce additional $\mathrm{HCHO}$, with a net conversion of $\mathrm{OH}$ into $\mathrm{HO}_{2}$ (Tie et al., 2003). As a result $\mathrm{CH}_{3} \mathrm{OH}$ is thought to be a significant global source of both HCHO (Millet et al., 2006) and, ultimately, CO (Duncan et al., 2007), which will have feedbacks via the additional scavenging of $\mathrm{OH}$. For a more information regarding the global effects of this biogenic emission the reader is referred to the study by Tie et al. (2003).

Finally, Table 6 lists both the global and tropical burdens for the nitrogen and carbon budgets, in order to assess the importance of the African continent on the global troposphere. Comparing the BASE and LATH simulations shows that, for the LATH simulation, the repartitioning of nitrogen results in a higher fraction being stored in the longer lived reservoir species PAN and ORGNTR, which increases the amount of nitrogen sequestrated by $\sim 3 \%$ for the global troposphere. This goes some way to explaining the reduction in the global production of $\mathrm{O}_{3}$ shown in Table 3. For isoprene, there is also a $\sim 3 \%$ reduction in the global burden in the LATH simulation, which again has implications for the night-time destruction of $\mathrm{O}_{3}$ and the production of (e.g.) ALD2 and OLE. This also compensates for the missing biogenic $\mathrm{HCHO}$ in the
BASE simulation. For the organic carbon flux there is an increase of $\sim 44 \%$ in C-C bonds (PAR) in the LATH simulation as a direct result of the increase in the global biogenic carbon flux. Moreover, the global burden of ALD2 also increases $\sim 6 \%$, which subsequently increases the fraction of nitrogen stored as PAN as a result of an increase in the pre-cursors.

Analysing the corresponding changes for the NOSOIL simulation shows the largest changes are for PAN and ORGNTR, with the global burden of $\mathrm{HNO}_{3}$ remaining relatively constant. This is a result of the reduction in $[\mathrm{OH}]$ which reduces the oxidation of isoprene by $\sim 8 \%(\sim 10 \%$ in the tropics), and PAR by $\sim 2 \%$ ( $\sim 5 \%$ in the tropics). Both of these are pre-cursors of ALD2, which causes a reduction in the fraction of nitrogen stored as PAN and ORGNTR. This acts as a small compensating effect for the lack of NO from soils with respect to the availability of reactive nitrogen. For the NOBIO simulation a comparison of the global burdens shows that emissions of BVOCs from Africa account for $\sim 1.5 \%$ of ALD2, $\sim 2.5 \%$ of OLE and $\sim 5 \%$ of PAR in the global troposphere $(\sim 10 \%, \sim 4 \%$ and $\sim 14 \%$ in the tropics, respectively). This is a direct effect rather than from oxidation products of other species as shown by the equal burdens in isoprene. This also has consequences for the $\mathrm{NO}_{\mathrm{x}}$ budget as shown by the $\sim 2.5 \%$ increase in the global burden of ORGNTR, although the influence on tropospheric $\mathrm{O}_{3}$ is marginal as shown above.

\section{Comparisons with observations}

In this section we assess how the TM4_AMMA model performs for the African Continent by comparing co-located model output with a host of different measurement data. Given that the differences between the NOBIO run and LATH run were found to be rather small in terms of differences in the tropospheric $\mathrm{O}_{3}$ burden we omit this sensitivity test from the following comparisons for brevity and in order to focus the discussion on the most important differences. 
Figure 8 shows comparisons of tropospheric $\left[\mathrm{O}_{3}\right]$ against the MOZAIC data sampled during the take-off and landing of passenger aircraft from Windhoek in Namibia $\left(22.5^{\circ} \mathrm{S}\right.$, $\left.17.5^{\circ} \mathrm{E}\right)$ for all seasons during 2006. The sampling frequency is approximately once every two days resulting in a statistically robust dataset. Moreover, profiles are taken during both daytime and nighttime therefore capturing the diurnal variation that occurs for tropospheric $\mathrm{O}_{3}$. In general, although the agreement is rather good for both the BASE and LATH simulations, the LATH simulation does result in a moderately better agreement for the mid- to UT using the current experimental setup, although this is dependent on the particular season (compare JJA vs SON). The largest deviation from the observed average occurs during the SON season, where all simulations underestimate values by $\sim 10$ $15 \%$ in the mid- to UT. In order to investigate this further an additional sensitivity test was performed where a daily cycle was imposed on the daily emission of trace species from biomass burning, as observed using satellites (e.g. Boersma et al., 2008), and the injection heights were increased to $2 \mathrm{~km}$ in the tropics following observations by Labonne et al. (2007). However, this only resulted in a relatively insignificant improvement in the agreement for season SON, suggesting that this is not the principal cause.

When compared to the MOZAIC seasonal averages the model tends to over-estimate surface ozone by $\sim 50 \%$ throughout the entire year, where the stratospheric contribution is shown by means of a chemically active $\mathrm{O}_{3}$ tracer for stratospheric $\mathrm{O}_{3}$ similar to that described in Lelieveld and Dentener (2000). For JJA this accounts for $\sim 20 \%$ of the tropospheric $\mathrm{O}_{3}$ profile measured at Windhoek as shown in Fig. 8c, although this does not impact on the quality of the comparison at the surface as seen by comparing the other seasons. For the NOSOIL run (shown as the black line) the profile tends to underestimate the values of the seasonal average obtained from the MOZAIC measurements throughout the year, especially for season DJF where the emission of NO from soil are maximal in this region of Africa (see Fig. 1). For this season soil $\mathrm{NO}_{\mathrm{x}}$ accounts for between $\sim 10-15 \%$ of the TTOC over Africa near the airport (see Sect. 4).

Figure 9 shows a similar comparison in the UT against the MOZAIC dataset, this time exploiting the measurements taken at the cruise altitude made by the passenger aircraft traveling to and from Frankfurt, Germany. Here we choose to show comparisons for March, June, September and December 2006 to highlight the monthly variability in the both the measurements and the simulations. The contributions due to stratospheric intrusions are again shown using the chemically active $\mathrm{O}_{3}$ tracer in order to assess whether the in situ formation of $\mathrm{O}_{3}$ in the troposphere is the dominating term. The observations show the meridional gradient which has been previously identified by both Sauvage et al. (2007) and Maunois et al. (2008), who have derived a gradient in the UT $\left[\mathrm{O}_{3}\right]$ of $1.13 \pm 0.17 \mathrm{ppbv} / \mathrm{deg}$ latitude and $0.94 \pm 0.18 \mathrm{ppbv} / \mathrm{deg}$ latitude, respectively. The extent of the agreement with the mea-
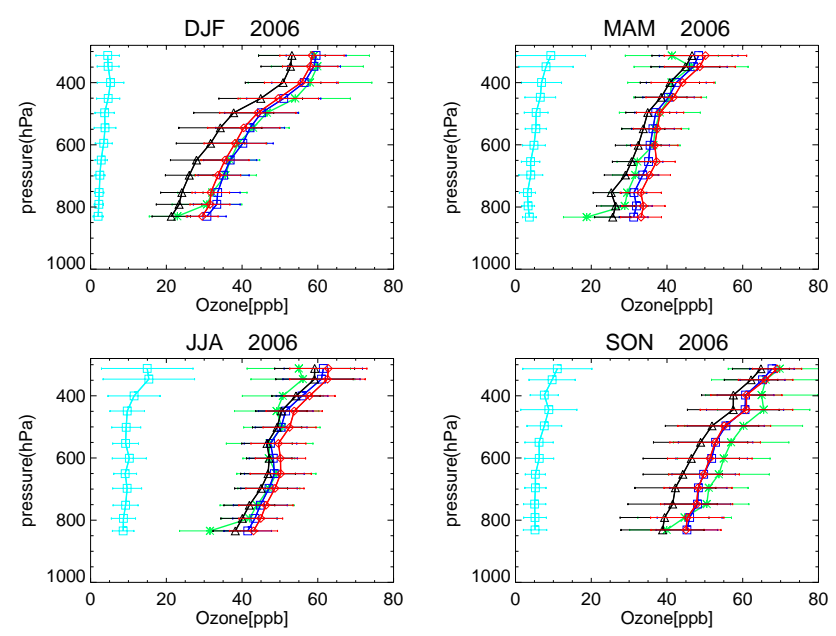

Fig. 8. Comparisons of co-located tropospheric ozone profiles for all seasons compared to MOZAIC take-off and landing measurements from Windhoek in Namibia $\left(22.5^{\circ} \mathrm{S}, 17.5^{\circ} \mathrm{E}\right)$. The results from three simulations are shown: (red) BASE, (deep blue) LATH and (black) NOSOIL, and compared against an average of the available measurements (green).The contribution due to stratospheric ozone intrusions is also shown (light blue) using a chemically active ozone tracer, as taken from the LATH run. The error bars represent the $1-\sigma$ deviation from the mean.
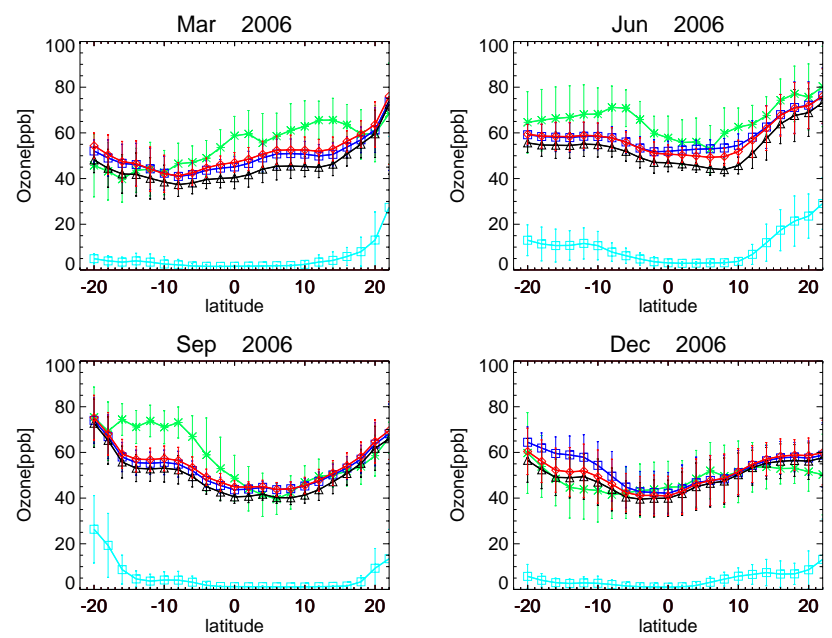

Fig. 9. Comparisons of upper tropospheric ozone as compared to MOZAIC in-flight measurements from Windhoek in Namibia $\left(22.5^{\circ} \mathrm{S}, 17.5^{\circ} \mathrm{E}\right)$ to Frankfurt in Germany $\left(50.0^{\circ} \mathrm{N}, 8.6^{\circ} \mathrm{E}\right)$. The colour key is identical to that used in Fig. 10. The error bars indicate the $1-\sigma$ deviation from the mean.

surements varies between the different simulations, although the largest deviation is again that for the NOSOIL run indicating that biogenic $\mathrm{NO}_{\mathrm{x}}$ is important for $\left[\mathrm{O}_{3}\right]$ at altitudes well above the boundary layer. This agrees with the conclusions of a similar sensitivity study performed by Maunois et al. (2008), who used a mesoscale model for July 2006 along 
with the MOZAIC data over Africa, although here we extend the domain of the comparison to $20^{\circ} \mathrm{S}$ and show various months during the course of the year. The contribution from STE is quite marked in the extra-tropics and generally results in a good agreement at latitudes $>10^{\circ} \mathrm{N}$. However, although the vertical resolution of TM4_AMMA is defined by the vertical levels available in the ECMWF meteorological fields in the tropical tropopause region it still maybe insufficient to capture all intrusions from the stratosphere. Moreover, the climatological boundary conditions which we adopt (Fortuin and Kelder, 1998) could also impose their own signature. None of the simulations can capture the increases in $\mathrm{UT} \mathrm{O}_{3}$ observed directly over regions where intense biomass burning activity occurs (e.g. $0-20^{\circ} \mathrm{N}$ in March and $0-20^{\circ} \mathrm{S}$ in September). It is interesting to see that for $0-10^{\circ} \mathrm{N}$ (June) and $10-20^{\circ} \mathrm{S}$ (December) there is an appreciable difference between the BASE and LATH profiles. Considering that the biomass burning inventories are identical in both simulations, this must be related to differences in the biogenic $\mathrm{NO}_{\mathrm{x}}$ inventories. This shows either that the biogenic NO source strength may be too high in the LATH inventory for December in southern Africa during 2006 or that the convective transport from the boundary layer is too efficient.

In order to assess the performance of the parameterization for convective transport directly below the flight transect we include some passive tracers in the simulations. Figure 10 shows the corresponding distribution of the four convective tracers for the corresponding months shown in Fig. 9. Here the concentrations are fixed at $100 \mathrm{pptv}$ below $850 \mathrm{hPa}$ and each tracer given a fixed atmospheric lifetime of 20 days. The area over which each tracer is defined is equal to that used for the segregated emission totals shown in Fig. 1. At the cruise altitudes concentrations are $<10 \mathrm{pptv}$ for all of the months shown, indicating that the air is aged by several days before it reaches the UT. This allows time for the photochemical production of $\mathrm{O}_{3}$ to occur at lower altitudes, which is then uplifted to the flight altitude. In general, the strength of the convective transport is stronger from southern Africa and Guinea than the other regions. For these two regions the maximal emission of pre-cursors from biomass burning occurs between July-September and December-January, respectively, where the magnitude of the annually integrated emission fluxes for Guinea are twice those for southern Africa (not shown). Bian et al. (2007) have shown that the variability between different biomass burning emission datasets is larger for southern Africa than for northern Africa as a result of the differences in the intensities between fires in each region. From Fig. 9 it can be seen that for March, June and September the model under predicts the MOZAIC measurements for certain latitudes. When accounting for the regional differences in the release of soil NO and the seasonality in the biomass burning activity, this suggests that the strength of the convective activity in the model from southern Africa is too weak during June and September, whilst being too strong in December. Moreover, possible deficien-
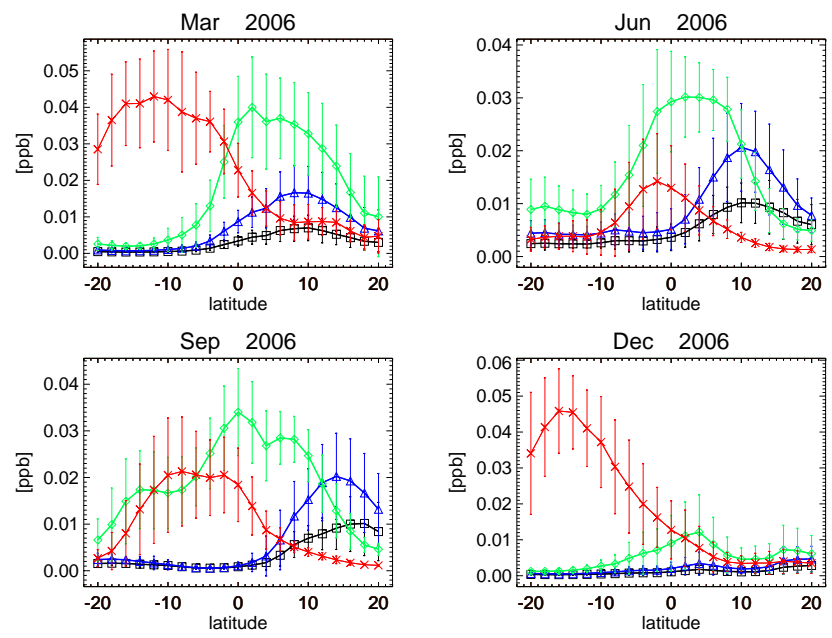

Fig. 10. Comparisons of the four passive tracers used to quantify the strength of convective activity below the MOZAIC flight tracks from Windhoek in Namibia $\left(22.5^{\circ} \mathrm{S}, 17.5^{\circ} \mathrm{E}\right)$ to Frankfurt in Germany $\left(50.0^{\circ} \mathrm{N}, 8.6^{\circ} \mathrm{E}\right)$. The colour key for the four passive tracer species are as follows: (black) Saharan, (blue) Sahel, (green) Guinea and (red) southern Africa. The error bars indicate the 1- $\sigma$ deviation from the mean.

cies in the quality of the emissions for southern Africa could also play a role. Finally, the agreement between the model and MOZAIC measurements between $0-10^{\circ} \mathrm{N}$ is rather good during December but gets worse for March, where the contribution to the biomass burning emission from all regions become similar, except for Sahara (not shown). Considering that the contribution from southern Africa increases during March (see Fig. 10) implies that the emission flux in southern Africa is too low.

Figure 11 shows a comparison of co-located ozone profiles for seasons DJF and JJA with measurements from both the SHADOZ network (Thompson et al., 2003) and those specifically measured during the AMMA project (Thouret et al., 2009). Here only model profiles for the specific measurement dates are averaged to ensure that a consistent comparison is performed. The quality of the comparison at each site is somewhat dependent on the season as would be expected considering the seasonality of the regional emission sources. The differences between the BASE and LATH simulations appear to be quite small in spite of the variations in the seasonality of the emissions, although at Cotonou $\left(6.6^{\circ} \mathrm{N}\right.$, $2.2^{\circ} \mathrm{E}$ ) there is a noticeable difference in the mid-troposphere during season DJF. This lack of difference between emission inventories is surprising considering the comparisons shown in Fig. 4 and suggests that the temporal differences near the sampling sites are not so large. The worst agreement occurs for Cotonou as a result of exceptional values of $\left[\mathrm{O}_{3}\right]$ which were measured around $700-800 \mathrm{hPa}$ at the site during December and which were attributed to an unknown local source (Thouret et al., 2009). Although there are instances 

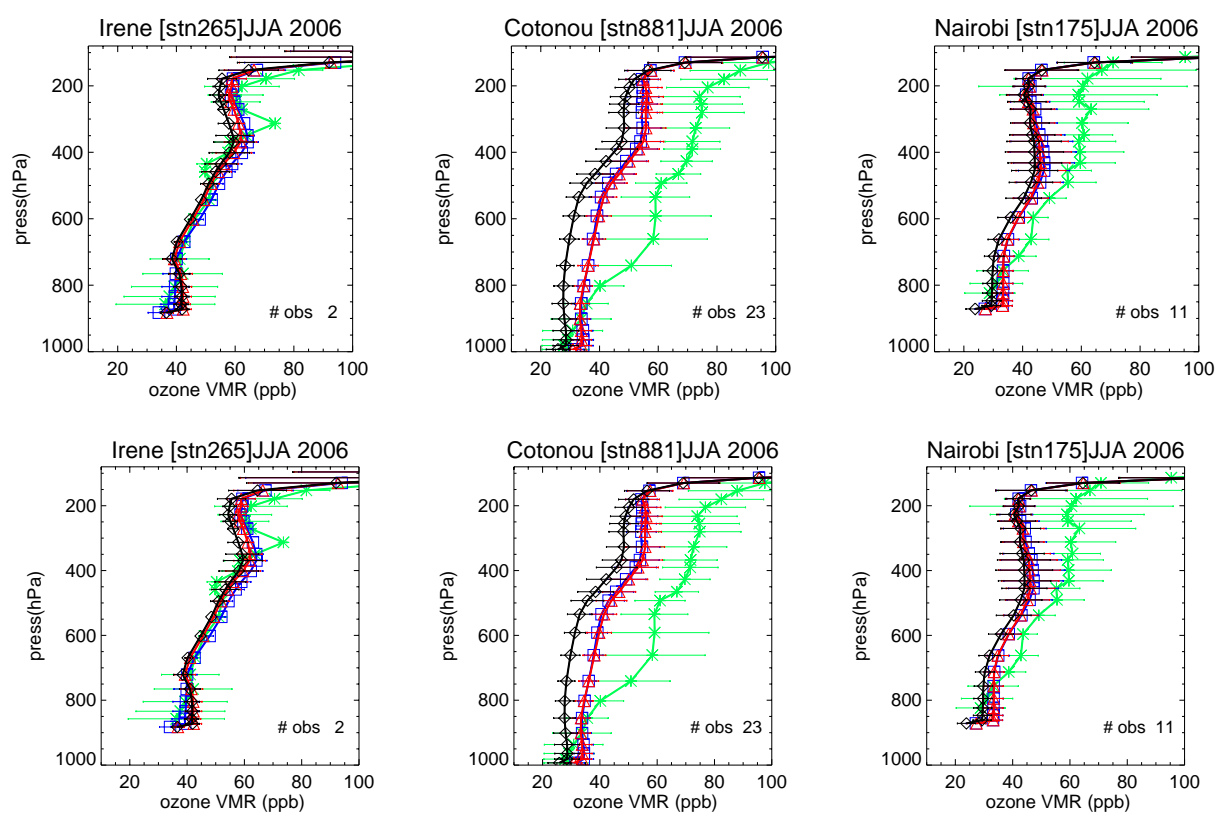

Fig. 11. Comparisons of co-located tropospheric ozone profiles for seasons DJF (top) and JJA (bottom). The soundings shown are taken from (left to right) Irene $\left(25.9^{\circ} \mathrm{S}, 28.2^{\circ} \mathrm{E}\right)$, Cotonou $\left(6.6^{\circ} \mathrm{N}, 2.2^{\circ} \mathrm{E}\right)$ and Narobi $\left(1.3^{\circ} \mathrm{S}, 36.8^{\circ} \mathrm{E}\right)$, taken from the SHADOZ database $($ Thompson et al., 2003). The results from three simulations are shown: (red) BASE, (blue) LATH and (black) NOSOIL, and compared against an average of the available measurements (green). The number of observations used for each comparison is shown in the lower left corner of each plot and the error bars indicate the $1-\sigma$ deviation from the mean.

where TM4_AMMA performs rather well (e.g. Irene during JJA) the model does not have the ability to capture the "peaks" in tropospheric $\mathrm{O}_{3}$ that occur between $700-800 \mathrm{hPa}$ (e.g. Cotonou during DJF). These lower-tropospheric maxima have been ascribed to air masses transported into the region by (e.g.) the Harmattan and African Easterly Jet (AEJ), and thus have different chemical histories (Sauvage et al., 2005). The quality of the comparison shows that under the current configuration the model has difficulty in being able to capture the vertical fine structure observed in the sondes, where Sauvage et al. (2005) have shown that, in principle, the ECMWF meteorological fields can capture such events. For the UT, the differences are relatively large, which is not consistent with the comparisons made against the MOZAIC measurements shown in Fig. 8. This suggests that the low sampling frequency for each season, and the large variability that occurs between such samples (as shown by the 1- $\sigma$ error bars) hinders the quality of the comparisons. Moreover, the use of homogenous monthly fluxes for pre-cursor emissions from all sources also introduces inaccuracies concerning the variability observed in the model. Some improvement could possibly be made to the simulations by adopting the 8-day biomass burning emission files available from the GFEDv2 inventory.

Again the NOSOIL run exhibits the worst overall agreement of all simulations for all sites, although in some circumstances, when the regional soil NO emissions are low, the differences between model profiles can be rather small (e.g. Nairobi during DJF). This supports the conclusion that the effect of soil $\mathrm{NO}_{\mathrm{x}}$ on tropospheric $\mathrm{O}_{3}$ formation is not strictly limited to the boundary layer when integrated over time. Moreover, this also shows that a global CTM can capture the same features as those simulated by meso-scale models (Saunois et al., 2008; Delon et al., 2008), whose run times are restricted to a number of days. When comparing results from the additional sensitivity test with the daily cycle imposed on the biomass burning emissions and increased injection heights, the resulting model profiles exhibited a few ppbv less in both the mid- and upper troposphere, thus degrading the quality of the comparisons. Another possible cause for the disagreement is that the convective parameterization does not provide enough convective mixing of precursors and/or $\mathrm{O}_{3}$ out of the boundary layer, as shown for the MOZAIC in-flight measurements, although regional emission sources are likey to have much more influence for the sonde measurements in the lower levels.

Figure 12 shows a comparison of interpolated model output against a composite of the tropospheric $\mathrm{O}_{3}$ measurements taken along the flight tracks of the French and German Falcon and the British BAe146, all of which participated in the AMMA measurement campaign during July and August 2006. With the exception of the M55-Geophysica measurements, the observations are identical to those shown in Janicot et al. (2008). In the lower troposphere the observations show that $\left[\mathrm{O}_{3}\right]$ typically varies between $30-40 \mathrm{ppbv}$, although there are instances where the variation is much 
greater. In the upper troposphere there is a wide variation of values ranging between $30-80 \mathrm{ppbv}$, although the median is around $50-55 \mathrm{ppbv}$. Some extreme events are also captured around $5^{\circ} \mathrm{N}$ in the mid-troposphere where $\left[\mathrm{O}_{3}\right]$ reaches between $80-100$ ppbv (red/black points in Fig. 11a). In general all of the simulations fail to emulate the correct variability shown in the observations. Moreover, there are values of $\sim 50 \mathrm{ppbv}$ in the lower troposphere around $12^{\circ} \mathrm{N}$ in all simulations. The similarity between the LATH and NOSOIL simulations shows that the cause of these high values are not due to the peak in $\mathrm{NO}$ emissions from soils between $0-10^{\circ} \mathrm{N}$ (see Fig. 1) but possibly transport of $\mathrm{O}_{3}$ from other regions. Conversely, the highest values which occur in the lower troposphere around $5^{\circ} \mathrm{N}$ are also not captured by the model in any of the simulations.

For the upper troposphere is can be seen that the BASE simulation has moderately higher $\left[\mathrm{O}_{3}\right]$ but still underestimates the high values observed up the column and at around $\sim 250 \mathrm{hPa}$. For the NOSOIL simulation, some of the low $\left[\mathrm{O}_{3}\right]$ which occur around $15^{\circ} \mathrm{N}$ are also seen in the measurements indicating that some variability in the soil NO emission must occur over the measurement period. This is most probably due to variations in the amount of soil $\mathrm{NO}_{\mathrm{x}}$ released throughout the month as observed by Stewart et al. (2008), which is not accounted for in the model as a result of using a fixed emission flux for the entire month from the 12 year average. Short periods of enhanced NO emissions occur after periods of intense rainfall and the representation of this in any model is important for capturing such events (Adon et al., 2009; Delon et al., 2009) and could also explain why TM4_AMMA fails to capture the higher $\left[\mathrm{O}_{3}\right]$ events. Therefore, it seems necessary to attempt to incorporate this into any future biogenic emission inventory. Considering that the inter-annual variability in rainfall is relatively high during the WAM (e.g. Long et al., 2000), it maybe worthwhile to try and segregate biogenic emissions into a weekly frequency to try and improve on the current 12 year average.

Figures $13 \mathrm{a}-\mathrm{c}$ show comparisons of the monthly means for surface $\mathrm{O}_{3}, \mathrm{NO}_{2}$ and $\mathrm{HNO}_{3}$ from the model simulations with the corresponding monthly means from measurements taken at a selection of measurement sites from the IDAF network (IGAC/DEBTS/Africa International Global Atmospheric Chemistry/Deposition of Biogeochemically Important Trace Species/Africa), respectively. Further details on the IDAF measurement program can be found at the following web address http://obs-mip.fr/idaf. These sites are principally located between $0-15^{\circ} \mathrm{N}$ and $\pm 10^{\circ}$ longitude and are, therefore, representative of the great ecosystems of western Equatorial Africa (Martins et al., 2007; Galy-Lacaux et al., 2009). For some months, no measurements are available at certain sites (which are represented as a zero value in the Figures). In general the surface $\mathrm{O}_{3}$ measured across all sites ranges between $10-30 \mathrm{ppbv}$, where higher values are typically occur during the summer months. When comparing both the BASE and LATH simulations the model consistently
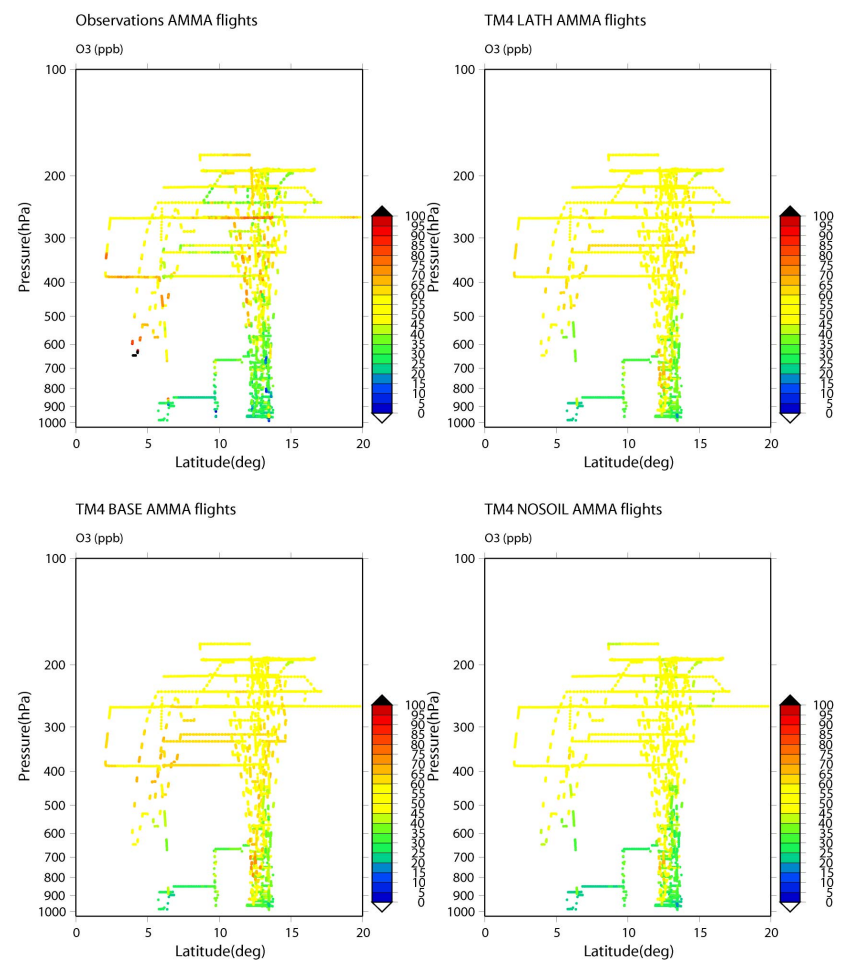

Fig. 12. A comparison of composite $\mathrm{O}_{3}$ measurements taken above Africa against TM4_AMMA output for the various simulations. The figures show the composite of observations for tropospheric $\mathrm{O}_{3}$ from the various aircraft (top left), the LATH run (top right), the BASE run (bottom left) and the NOSOIL run (bottom right).

over predicts surface $\left[\mathrm{O}_{3}\right]$ by between $\sim 50-100 \%$, although the seasonal cycle is captured to some degree. The BASE simulation typically shows higher values than the LATH simulation, which agrees with the comparisons shown in Figs. 8-10. Similar plots to those shown in Sect. 4 for a chemically active tracer included to assess the influence of stratospheric $\mathrm{O}_{3}$ indicates that there is a $\sim 2-5$ ppbv contribution at the surface near the measurement sites (not shown), which accounts for $\sim 10-15 \%$ of the surface values. The worst agreement is shown for Zoétélé $\left(3.1^{\circ} \mathrm{N}, 11.6^{\circ} \mathrm{E}\right)$, which is situated in a tropical forest. At this location a contributing factor to the low values in the measurements is that tropical forests are considered to be a substantial sink as a result of all the different strata of vegetation under the canopy contributing to both the deposition and chemical destruction (Cros et al., 1992). Such detail is obviously not included in a global model, where the disagreement is compounded by the fact that the area contained in a typical grid-cell in the model covers a range of different vegetation and land types. In the NOSOIL run at some measurement sites there is a clear decrease in $\left[\mathrm{O}_{3}\right]$ of up to $\sim 50 \%$ during certain months. This is a cumulative effect of a reduction in the local production and that transported over the measurement site from other regions. However, in many instances removing the soil 

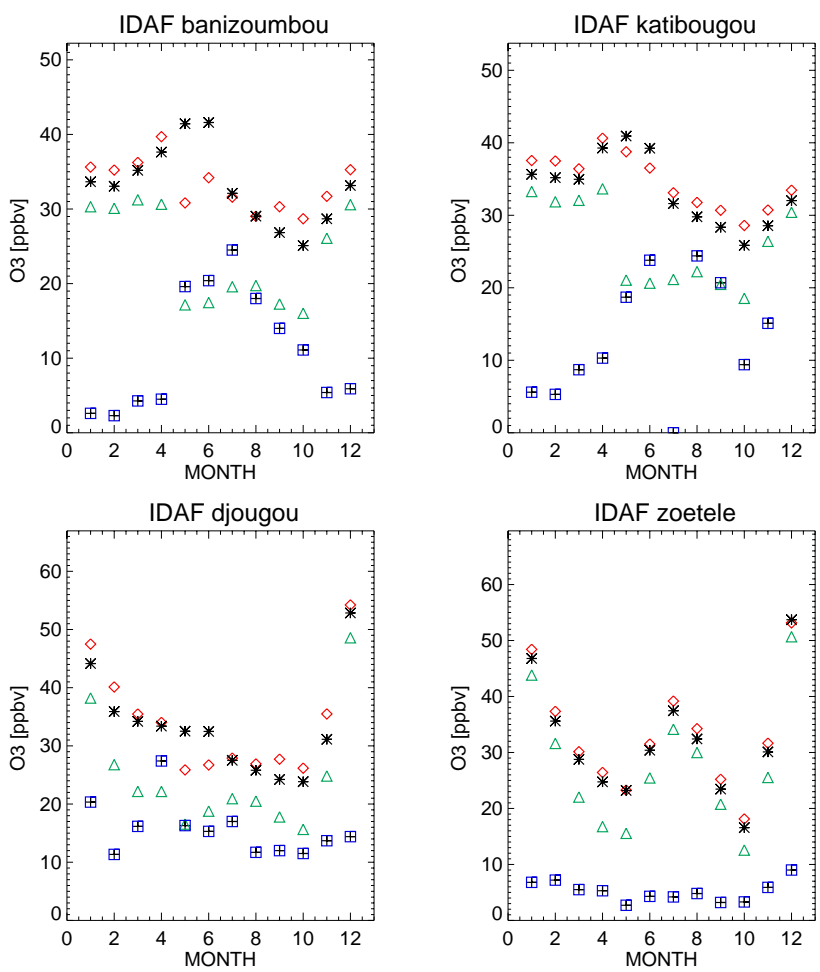

Fig. 13a. Comparisons of monthly mean values for surface $\mathrm{O}_{3}$ at a selection of IDAF measurement sites, namely: Banizoumbou, Niger $\left(13.3^{\circ} \mathrm{N}, 2.4^{\circ} \mathrm{E}\right)$, Katibougou, Mali $\left(10.5^{\circ} \mathrm{N}, 7.3^{\circ} \mathrm{W}\right)$, Djougou $\left(9.4^{\circ} \mathrm{N}, 1.6^{\circ} \mathrm{E}\right)$, Benin and Zoétélé $\left(3.1^{\circ} \mathrm{N}, 11.5^{\circ} \mathrm{E}\right)$, Cameroon. Model results from all simulations are shown: where $(\diamond)$ BASE, (*) LATH, $(\Delta)$ NOSOIL and $(\square)$ are the measurements. The errors associated with the measurements are $\pm 10 \%$ of the monthly value according to Adon et al. (2009). The variability associated with the model values is typically $\pm 20 \%$.

$\mathrm{NO}_{\mathrm{x}}$ has little effect on $\left[\mathrm{O}_{3}\right]$ (e.g. Zoétélé for all seasons). Considering that tropospheric ozone has a typical lifetime of $\sim 23$ days in these runs (see Sect. 6), the majority must be formed from other sources, notably biomass burning, as found in Adon et al. (2009) (see below).

For $\left[\mathrm{NO}_{2}\right]$, two maxima are typically visible during the year for the dry savannah, as determined from an analysis of the decadel dataset measured at both Banizoumbou and Katibougou $\left(10.5^{\circ} \mathrm{N}, 7.3^{\circ} \mathrm{W}\right)$ by Adon et al. (2009). The first occurs during May-June at the beginning of the rainy season, which is attributed to soil $\mathrm{NO}_{\mathrm{x}}$ emissions, and the second related to a biomass burning source. For the wet savanna and forested sites (i.e. Djougou and Zoétélé) the seasonal cycle is less marked thus a regional biomass burning source is thought to be more important. When comparing the model monthly means with the measurements it can be seen that the model exhibits higher $\left[\mathrm{NO}_{2}\right]$ during winter for both the BASE and LATH runs, whereas for the summer the agreement is much better. Moreover, the temporal differences between both emission inventories become more ob-
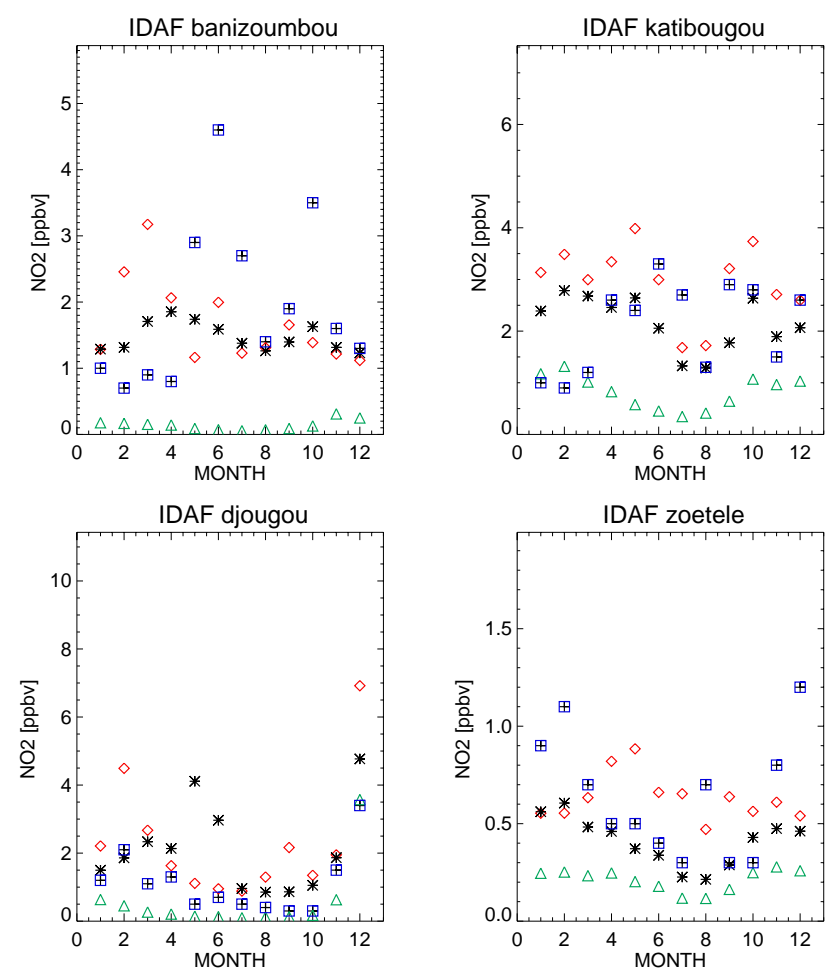

Fig. 13b. As for Fig. 13a except for $\mathrm{NO}_{2}$. The errors associated with the measurements are $\pm 9.8 \%$ of the monthly value according to Adon et al. (2009). The variability associated with the model values is typically $\pm 50 \%$.

vious, where the distribution of $\mathrm{NO}_{\mathrm{x}}$ in the POET inventory results in more local emissions near the measurement sites. This generally results in an over-prediction compared to the LATH inventory, indicating that both the timing and temporal distribution is better in the LATH run (see comparison for Katibougou, Mali in Fig. 13b). The NOSOIL run shows that the seasonal cycle at Banizoumbou is almost entirely due to soil $\mathrm{NO}_{\mathrm{x}}$, whereas at Katibougou there is a greater contribution due to biomass burning. That said, the emission of NO from soils appears to be too high at Banizoumbou (as shown by the comparison of the LATH run during winter). At Katibougou the model over-predicts $\left[\mathrm{NO}_{2}\right]$, for the earlier months, whereas the agreement is good for April-May and the end of the year. At this site the biomass burning contribution helps to capture the correct seasonal variability.

For $\mathrm{HNO}_{3}$ the detection limit of the measurement technique is $\sim 0.1 \mathrm{ppbv}$, thus for many of the months the $\left[\mathrm{HNO}_{3}\right]$ measured is at, or below, this threshold. The model generally over predicts the formation and/or the lifetime of $\mathrm{HNO}_{3}$ during winter, whilst under predicting during the summer. Therefore some degree of a signature is present from the $\left[\mathrm{NO}_{2}\right]$ comparison. For summer, the conversion of reactive $\mathrm{NO}_{\mathrm{x}}$ into $\mathrm{HNO}_{3}$ is not optimal in spite of the high $\left[\mathrm{O}_{3}\right]$ (and thus $[\mathrm{OH}]$ ), which should enhance the formation rate of $\mathrm{HNO}_{3}$. Unfortunately no corresponding data is available for 

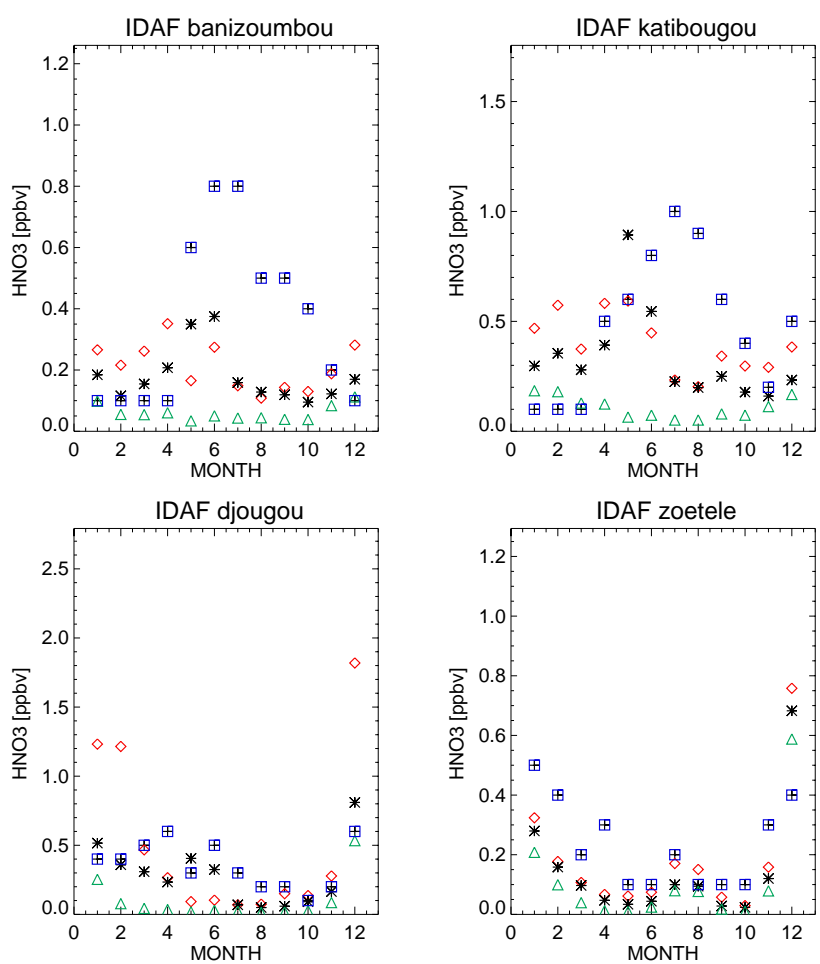

Fig. 13c. As for Fig. 13a except for $\mathrm{HNO}_{3}$. The detection limit for $\left[\mathrm{HNO}_{3}\right]$ is $0.1 \mathrm{ppbv}$ and the errors associated with the measurements are $\pm 20 \%$ of the monthly value according to Adon et al. (2009). The variability associated with the model values is typically $\pm 15 \%$.

either PAN or organic nitrates, which would be instructive in terms of determining whether the concentrations of these species are also under predicted (i.e.) whether there is too little nitrogen in the system as a result of the low $\mathrm{NO}_{\mathrm{x}}$ emissions for this season. Moreover, this would also allow an assessment of whether the cause is either a deficiency associated with the chemical mechanism (such as the recently proposed production of $\mathrm{HNO}_{3}$ involving $\mathrm{NO}$ and $\mathrm{HO}_{2}$, Butkovskaya et al., 2007), an over estimation of the deposition flux, a missing source term or whether the emission of $\mathrm{NO}_{\mathrm{x}}$ is too high for this year from either biomass burning or biogenic sources. For the NOSOIL run the corresponding comparisons show that this source accounts for $\sim 50 \%$ of the local production during winter and over $75 \%$ during the summer, as would be expected considering the $\left[\mathrm{NO}_{2}\right]$ comparisons.

\section{Conclusions and outlook}

In this study we have applied two recently developed inventories for biogenic emissions (provided as part of the POET and RETRO databases) in a state-of-the-art CTM for the purpose of investigating the effect on the composition of the tropical troposphere over Africa. We have found that the seasonality and temporal distribution of isoprene, biogenic volatile organic carbon and NO emissions are quite different, which introduces differences with respect to both regional and global $\left[\mathrm{O}_{3}\right]$, the fraction of reactive nitrogen sequestrated into reservoir compounds and the total carbon loading in the tropical troposphere. In terms of the chemical budget, the POET biogenic emission inventory results in a more chemically active troposphere, where the atmospheric lifetimes of $\mathrm{CH}_{4}$ and $\mathrm{CO}$ decrease by $\sim 1.5 \%$ and $\sim 4 \%$, respectively. For the Lathière et al. (2006) inventory, there is an increase in the total nitrogen lost by wet deposition of $\sim 5 \%$ which contributes to a lower tropospheric ozone burden. This also introduces differences in the total tropical ozone column that is calculated between both inventories, which has the potential to improve comparisons between CTM's and satellite instruments (e.g. Valks et al., 2003). For the biogenic volatile organics, there is a $\sim 3 \%$ reduction in the global isoprene burden in the inventory of Lathière et al. (2006), along with increases in alkanes, aldehydes and olefins of between $\sim 1.5-5 \%$ as a result of the additional direct emissions. When comparing simulations against a suite of in situ measurements the inventory of Lathière et al. (2006) results in a better agreement in the majority of cases.

Sensitivity studies have shown that the emission of NO from soils in Africa are responsible for between $\sim 2-45 \%$ of tropospheric $\left[\mathrm{O}_{3}\right]$ over equatorial Africa. This influences the oxidative capacity of the African troposphere in the region, which has implications regarding the export of trace species via the perturbations to the atmospheric lifetimes of abundant trace species. Therefore, CTM studies which focus on quantifying the long-range transport of trace gases should ensure that they adopt recent biogenic emission inventories to account for changes in local climate and/or land-use. For biogenic volatile organic compounds the effects on tropospheric $\left[\mathrm{O}_{3}\right]$ seem to be rather minimal. The use of tagged tracers shows that biogenic $\mathrm{CO}$ emissions are responsible for $\sim 15 \%$ of the global burden of $\mathrm{CO}$ of the direct emissions in Africa. Moreover, analyzing the chemical budget shows that the biogenic emissions from the African Continent are responsible for $\sim 1.5 \%$ of ALD2, $2.5 \%$ of OLE and $\sim 5 \%$ of PAR in the global troposphere. This has an influence on the oxidative capacity via the scavenging of $\mathrm{OH}$, especially near the source regions.

Although the 12 year average for biogenic emissions provided by Lathière et al. (2006) improves the overall performance of TM4_AMMA in the tropics when compared with observations, there are still problems in that the variability seen by the measurements are often not captured by the simulations. This implies that more detail should be introduced regarding the temporal variability of such emissions when performing simulations for various time periods. For offline CTM modeling the incorporation of an online algorithm, such as that described in Ganzeveld and Lelieveld (2002), may not be feasible considering that constraints are often 
imposed on the complexity of any large-scale model in order to achieve realistic runtimes. Therefore, a step forward for offline modeling would be to extend the time period for which ORCHIDEE output is available in order to account for the further deforestation and desertification which has occurred in the last decade. Moreover, rather than assembling an multi-annual average, the emission fluxes could be supplied as monthly segregated emission estimates for each year similar to that provided for biomass burning emissions (e.g. van der Werf et al., 2006). By using meteorological data such as precipitation rates the degree of inter-annual variability could be improved which would improve large-scale simulations.

For future climates the emission of NO from soils will most likely increase by $\sim 20 \%$ by 2100 to $10.5 \mathrm{Tg} \mathrm{N} \mathrm{yr}^{-1}$, as suggested in Hauglustaine et al. (2005), as a result of the temperature increases and changes in vegetation which are predicted to occur in tropical regions. Associated changes will also occur for the BVOCs, where the total global carbon flux is predicted to double. This will most likely increase the weekly variability in tropospheric ozone production over Africa during the Wet Season where more intensive rainfall is imposed on a drier background environment introducing significant seasonal differences with respect to tropospheric ozone over Africa. Our studies also indicate that this will also affect the tropical marine environment over the Atlantic, where increases in the background VOC levels can be expected along with possible reductions in ozone thus increasing atmospheric lifetimes. The simultaneous increases in tropospheric water vapour may moderate this to some extent, although increased cloud cover would further dampen $\mathrm{OH}$ production. Our studies also indicate that the long-range transport of $\mathrm{CO}$ out of the region would also be enhanced which would have implications for back ground levels in the $\mathrm{SH}$.

Acknowledgements. The authors acknowledge the EU integrated project AMMA (African Monsoon Multidisciplinary Analysis) for the support network and funding. Based on a French initiative, AMMA was built by an international scientific group and is currently funded by a large number of agencies, especially from France, the United Kingdom, the United States and Africa. It has been the beneficiary of a major financial contribution from the European Community Sixth Framework Research Programme. Detailed information on scientific co-ordination and funding is available on the AMMA International Web site at www.amma-international.org. We are also grateful to Hans Schlager (DLR), Gerard Ancellet (Service d'Aeronomie) and the Facility for Airborne Atmospheric Measurements (FAAM) for permission to use the measurements taken during the AMMA measurement campaign. We also acknowledge both the POET and RETRO EU projects for providing the emission inventories for both used in this study and the INSU-CNRS (France), the European Network of Excellence ACCENT and the ICG Forschungszentrum Jülich (Germany) for providing the transportation and maintenance costs of the MOZAIC instrumentation onboard the Air Namibia aircraft. The MOZAIC database is managed by ETHER (CNES and INSU-CNRS, France). Finally, we thank the two anonymous referees who made suggestions which improved the readability of the manuscript.

Edited by: C. Reeves

\section{References}

Adon, M., Galy-Lacaux, C., Delon, C., Yoboué, V., Liousse, C., Lacaux, J. P., Pienaar, K., Al Ourabi, H., Dungall, L., Diop, B., Sigha, L., Lavenu, F., and Mougin, E.: Long-term measurements of sulphur dioxide, nitrogen dioxide, ammonia, nitric acid and ozone in Africa using passive samplers, Atmos. Chem. Phys. Discuss., submitted, 2009.

Aghedo, A. M., Schultz, M. G., and Rast, S.: The influence of African air pollution on regional and global tropospheric ozone, Atmos. Chem. Phys., 7, 1193-1212, 2007, http://www.atmos-chem-phys.net/7/1193/2007/.

Andres, R. J. and Kasgnoc, A. D.: A time-averaged inventory of subaerial volcanic sulfur emissions, J. Geophys. Res., 103, 25251-25261, 1998.

Atkinson, R., Baulch, D. L., Cox, R. A., Crowley, J. N., Hampson, R. F., Hynes, R. G., Jenkin, M. E., Rossi, M. J., Troe, J., and IUPAC Subcommittee: Evaluated kinetic and photochemical data for atmospheric chemistry: Volume II - gas phase reactions of organic species, Atmos. Chem. Phys., 6, 3625-4055, 2006, http://www.atmos-chem-phys.net/6/3625/2006/.

Bian, H., Chin, M., Kawa, R., Duncan, B., Arellano, A., and Kasibhatla, P.: Sensitivity of global CO simulations to uncertainties in biomass burning sources, J. Geophys. Res., 112, D23308, doi:10.1029/2006JD008376, 2007.

Boersma, K. F., Jacob, D. J., Eskes, H. J., Pinder, R. W., Wang, J., and van der A, R. J.: Intercomparison of SCIAMACHY and OMI tropospheric $\mathrm{NO}_{2}$ columns: Observing the diurnal evolution of chemistry and emissions from space, J. Geophys. Res., 113, D16S26, doi:10.1029/2007JD008816, 2008.

Butkovskaya, N. I., Kukui, A., and Le Bras, G.: $\mathrm{HNO}_{3}$ forming channel of the $\mathrm{HO}_{2}+\mathrm{NO}$ reaction as a function of pressure and temperature in the ranges of 72-600 Torr and 223-323 K, J. Phys. Chem. A, 111, 9047-9053, 2007.

Cros, B., Nganga, D., Minga, A., Fishman, J., and Brackett, V.: Distribution of tropospheric ozone at Brazaville, Congo, deterrmined from ozonesondes measurements, J. Geophys. Res., 97, 12869-12875, 1992.

Davidson, E. A.: Pulses of nitric oxide and nitrous oxide flux following wetting of dry soil: An assessment of probable sources and importance relative to annual fluxes, Ecol. Bull., 42, 149155, 1992.

Davidson, E. A. and Kingerlee, W.: A global inventory of nitric oxide emissions from soils, Nutr. Cycl. Agroecosys., 48, 37-50, 1997.

Delon, C., Serça, D., Boissard, C., Dupont, R., Laville, P., de Rosnay, P., and Delmas, R.: Soil NO emissions modeling using artificial neural network, Tellus B, 59B, 503-513, 2007.

Delon, C., Reeves, C. E., Stewart, D. J., Serça, D., Dupont, R., Mari, C., Chaboureau, J.-P., and Tulet, P.: Biogenic nitrogen oxide emissions from soils - impact on $\mathrm{NO}_{\mathrm{x}}$ and ozone over West Africa during AMMA (African Monsoon Multidisciplinary Experiment): modelling study, Atmos. Chem. Phys., 8, 2351-2363, 
2008 ,

http://www.atmos-chem-phys.net/8/2351/2008/.

Delon, C., Galy-Lacaux, C., Boone, A., Liousse, C., Serça, D., Adon, M., Diop, B., Akpo, A., Lavenu, F., Mougin, E., and Timouk, F.: Atmospheric nitrogen budget in Sahelian dry savannas, Atmos. Chem. Phys. Discuss., 9, 14189-14233, 2009, http://www.atmos-chem-phys-discuss.net/9/14189/2009/.

Duncan, B. N., Logan, J. A., Bey, I, Megretskaia, I. A., Yantosca, R. M., Novelli, P. C., Jones, N. B., and Rinsland, C. P.: Global budget of CO 1988-1997: Source estimates and validation with a global model, J. Geophys. Res., 112, D22301, doi:10.1029/2007JD008459, 2007.

Edwards, D. P., Emmons, L. K., Gille, J. C., Chu, A., Attie, J.-L., Giglio, L., Wood, S. W., Haywood, J., Deeter, M. N., Massie, S. T., Ziskin, D. C., and Drummond, J.: Satellite-observed pollution from Southern Hemisphere biomass burning, J. Geophys. Res., 111, D14312, doi:10.1029/2005JD006655, 2006.

Endresen, O., Sorgard, E., Sundet, J. K., Dalsoren, S. B., Isaksen, I. S. A., Berglen, T. F., and Gravir, G.: Emission from international sea transportation and environmental impact, J. Geophys. Res., 108(D17), 4560, doi:10.1029/2002JD002898, 2003.

Evans, M. J. and Jacob, D. J.: Impact of new laboratory studies of $\mathrm{N}_{2} \mathrm{O}_{5}$ hydrolysis on global model budgets of tropospheric nitrogen oxides and OH, Geophys. Res. Lett., 32, L09813, doi:10.1029/2005GL022469, 2005.

Fortuin, J. P. F. and Kelder, H.: An ozone climatology based on ozonesonde and satellite measurements, J. Geophys. Res., 103(D24), 31709-31734, 1998.

Galy-Lacaux, C., Laouali, D., Descroix, L., Gobron, N., and Liousse, C.: Long term precipitation chemistry and wet deposition in a remote dry savanna site in Africa (Niger), Atmos. Chem. Phys., 9, 1579-1595, 2009,

http://www.atmos-chem-phys.net/9/1579/2009/.

Ganzeveld, L. N., Lelieveld, J., Dentener, F. J., Krol, M. C., Bouwman, A. J., and Roelofs, G. J.: Global soil-biogenic $\mathrm{NO}_{\mathrm{x}}$ emissions and the role of canopy processes, J. Geophys. Res., 107(D16), 4298, doi:10.1029/2001JD001289, 2002.

Ganzeveld, L. N. and Lelieveld, J.: Impact of Amazonian deforestation on atmospheric chemistry, Geophys. Res. Lett., 31(6), L06105, doi:10.1029/2003GL019205, 2004.

Granier, C., Guether, A., Lamarque, J. F., Mieville, A., Muller, J. F., Olivier, J., Orlando, J., Peters, J., Petron, G., Tyndall, G., and Wallens, S.: POET - a database of surface emissions of ozone precursors, online available at: http://gcmd.nasa.gov/ records/GCMD_GEIA_POET.html, 2005.

Grewe, V., Dameris, M., Fichter, C., and Sausen, R.: Impact of aircraft $\mathrm{NO}_{\mathrm{x}}$ emissions. Part 1: Interactively coupled climatechemistry simulations and sensitivities to climate-chemistry feedback, lightening and model resolution, Meteorol. Z., 11(3), 177-186, 2002

Guenther, A., Hewitt, C. N., Erickson, D., Fall, R., Geron, C., Graedel, T., Harley, P., Klinger, L., Lerdau, M., McKay, W. A., Pierce, T., Scholes, B., Steinbrecher, R., Tallamraju, R., Taylor, J., and Zimmerman, P.: A global model of natural volatile organic compound emissions, J. Geophys. Res., 100, 8873-8892, 1995.

Guenther, A., Karl, T., Harley, P., Wiedinmyer, C., Palmer, P. I., and Geron, C.: Estimates of global terrestrial isoprene emissions using MEGAN (Model of Emissions of Gases and Aerosols from
Nature), Atmos. Chem. Phys., 6, 3181-3210, 2006, http://www.atmos-chem-phys.net/6/3181/2006/.

Hauglustaine, D. A., Lathière, J., Szopa, S., and Folberth, G. A.: Future tropospheric ozone simulated with a climatechemistry-biosphere model, Geophys. Res. Lett., 32, L24807, doi:10.1029/2005GL024031, 2005.

Houweling, S., Dentener, F. J., and Lelieveld, J.: The impact of non-methane hydrocarbon compounds on tropospheric photochemistry, J. Geophys. Res., 103(D9), 10673-10696, doi:10.1029/97JD03582, 1998.

Jaeglé, L., Martin, R. V., Chance, K., Steinberger, L., Kurosu, T. P., Jacob, D. J., Modi, A. I., Yoboué, V., Sigha-Nkamdjou, L., and Galy-Lacaux, C.: Satellite mapping of rain-induced nitric oxide emissions from soils, J. Geophys. Res., 109, D21310, doi:10.1029/2004JD004787, 2004.

Janicot, S., Thorncroft, C. D., Ali, A., Asencio, N., Berry, G., Bock, O., Bourles, B., Caniaux, G., Chauvin, F., Deme, A., Kergoat, L., Lafore, J.-P., Lavaysse, C., Lebel, T., Marticorena, B., Mounier, F., Nedelec, P., Redelsperger, J.-L., Ravegnani, F., Reeves, C. E., Roca, R., de Rosnay, P., Schlager, H., Sultan, B., Tomasini, M., Ulanovsky, A., and ACMAD forecasters team: Large-scale overview of the summer monsoon over West Africa during the AMMA field experiment in 2006, Ann. Geophys., 26, 25692595, 2008, http://www.ann-geophys.net/26/2569/2008/.

Krinner, G., Viovy, N., de Noblet-Ducoudré, N., Ogeé, J., Polcher, J., Friendlingstein, P., Ciais, P., Sitch, S., and Prentice, I. C.: A dynamic global vegetation model for studies of the coupled atmosphere-biosphere system, Global. Biogeochem. Cy., 19, GB1015, doi:10.1029/2003GB002199, 2005.

Labonne, M., Breon, F.-M., and Chevallier, F.: Injection height of biomass burning aerosols as seen from a spaceborne lidar, Geophys. Res. Lett., 34, L11806, doi:10.1029/2007GL029311, 2007.

Lathiére, J., Hauglustaine, D. A., Friend, A. D., De NobletDucoudré, N., Viovy, N., and Folberth, G. A.: Impact of climate variability and land use changes on global biogenic volatile organic compound emissions, Atmos. Chem. Phys., 6, 2129-2146, 2006, http://www.atmos-chem-phys.net/6/2129/2006/.

Lavoué, D., Liousse, C., Cachier, H., Stocks, B. J., and Goldammer, J. G.: Modeling of carbonaceous particles emitted by boreal and temperate wildfires at northern midlatitudes, J. Geophys. Res., 105, 26871-26890, 2000.

Lee, D. S., Brunner, D., Döpelheuer, A., Falk, R. S., Ardner, R. M., Lecht, M., Leech, M., Lister, D. L., and Newton, P. J.: Aviation emissions present-day and future, Meteorol. Z., 11(3), 141-150, 2002.

Lelieveld, J. and Dentener, F. J.: What controls tropospheric ozone?, J. Geophys. Res., 105(D3), 3531-3551, 2000.

Long, M., Entekhabi, D., and Nicholson, S. E.: Interannual variability in Rainfall, Water Vapor Flux and Vertical Motion, J. Climate, 13(21), 3827-3841, 2000.

Ludwig, J., Meixner, F. X., Vogel, B., and Förstner, J.: Soil-air exchange of nitric oxide: An overview of processes, environmental factors and modeling studies, Biogeochemistry, 52, 225-257, 2001.

Martins, J. J., Dhammapala, R. S., Lachmann, G., Galy-Lacaux, C., and Pienaar, J. J.: Long-term measurements of sulphur dioxide, nitrogen dioxide, nitric acid and ozone in southern Africa using 
passive tracers, S. Afr. J. Sci., 103(7-8), 336-342, 2007.

Meijer, E. W., van Velthoven, P., and Brunner, D. W.: Improvement and evaluation of the parameterization of nitrogen oxide production by lightning, Phys. Chem. Earth C, 26(8), 557-583, 2001.

Millet, D. B., Jacob, D. J., Custer, T. G., de Gouw, J. A., Goldstein, A. H., Karl, T., Singh, H. B., Sive, B. C., Talbot, R. W., Warneke, C., and Williams, J.: New constraints on terrestrial and oceanic sources of atmospheric methanol, Atmos. Chem. Phys., 8, 68876905, 2008,

http://www.atmos-chem-phys.net/8/6887/2008/.

Muller, J. F.: Geographical distribution and seasonal variation of surface emissions and deposition velocities of atmospheric trace gases, J. Geophys. Res., 97, 3787-3804, 1992.

Palmer, P. I., Jacob, D. J., Fiore, A., Martin, R. V., Chance, K., and Kurosu, T. P.: Mapping isoprene emissions over North America using formaldehyde column observations, J. Geophys. Res., 108(D6), 4180, doi:10.1029/2002JD002153, 2003.

Peters, W., Krol, M., Dentener, F., Thompson, A. M., and Lelieveld, J.: Chemistry-transport modeling of the satellite observed distribution of tropical troposheric ozone, Atmos. Chem. Phys., 2, 103-120, 2002,

http://www.atmos-chem-phys.net/2/103/2002/.

Potter, C. S., Matson, P. A., Vitousek, P. M., and Davidson, E. A.: Process modeling of controls on nitrogen tracer gas emissions from soils worldwide, J. Geophys. Res., 101, 1361-1377, 1996.

Redelspeger, J. L., Thorncroft, C. D., Diedhiou, A., Lebel, T., Parker, D. J., and Polcher, J.: African Monsoon Multidisiplinary Analysis - An international research project and field campaign, B. Am. Meteorol. Soc., 87, 1739-1746, 2006.

Russell, G. and Lerner, J.: A new finite-differencing scheme for the tracer transport equation, J. Appl. Meterol., 20, 1483-1498, 1981.

Sander, S. P., Friedl, R. R., Ravishankara, A. R., Golden, D. M., Kolb, C. E., Kuryllo, M. J., Molinda, M. J., Moortgart, G. K., Keller-Rudek, H., Finlayson-Pitts, B. J., Wine, P. H., Huie, R. E., and Orkin, V. L.: Chemical kinetics and Photochemical Data for Use in Atmospheric studies, Evaluation No 15, JPL-Publication 06-2, 2006.

Saunois, M., Mari, C., Thouret, V., Cammas, J.-P., Peyrillé, P., Lafore, J. P., Sauvage, B., Volz-Thomas, A., Nédélec, P., and Pinty, J. P.: An idealized two-dimensional approach to study the impact of the West African monsoon on the meridional gradient of tropospheric ozone, J. Geophys. Res., 113, D070306, doi:10.1029/2007JD008707, 2008.

Sauvage, B., Thouret, V., Cammas, J.-P., Gheusi, F., Athier, G., and Nédélec, P.: Tropospheric ozone over Equatorial Africa: regional aspects from the MOZAIC data, Atmos. Chem. Phys., 5, 311335,2005 ,

http://www.atmos-chem-phys.net/5/311/2005/.

Sauvage, B., Thouret, V., Cammas, J.-P., Brioude, J., Nédélec, P., and Mari, C.: Meridional ozone gradients in the African upper troposphere, Geophys. Res. Lett., 34, L03187, doi:10.1029/2006GL0285452, 2007.

Schumann, U. and Huntrieser, H.: The global lightning-induced nitrogen oxides source, Atmos. Chem. Phys., 7, 3823-3907, 2007, http://www.atmos-chem-phys.net/7/3823/2007/.

Shindell, D. T., Faluvegi, G., Stevenson, D. S., Krol, M. C., Emmons, L. K., and 38 others: Multi-model simulations of carbon monoxide: Comparison with observations and pro- jected near-future changes, J. Geophys. Res., 111, D08302, doi:10.1029/2006JD007100, 2006.

Stewart, D. J., Taylor, C. M., Reeves, C. E., and McQuaid, J. B.: Biogenic nitrogen oxide emissions from soils: impact on NOx and ozone over west Africa during AMMA (African Monsoon Multidisciplinary Analysis): observational study, Atmos. Chem. Phys., 8, 2285-2297, 2008,

http://www.atmos-chem-phys.net/8/2285/2008/.

Stevenson, D. S., Dentener, F. J., Schultz, M. G., Ellington, K., and 40 others: Multimodel ensemble simulations of present-day and near-future tropospheric ozone, J. Geophys. Res., 111, D08301, doi:10.1029/2005JD006338, 2006.

Thompson, A., Witte, J. C., Oltmans, S. J., Schmidlin, F. J., Logan, J. A., Fuijwara, M., Kirchhoff, V. W. J. H., Posny, F., Coetzee, G. J. R., Hoegger, B., Kawakami, S., Ogawa, T., Fortuin, J. P. F., and Kelder, H. M.: Southern Hemisphere Additional Ozonesondes (SHADOZ) 1998-2000 tropical ozone climatology 2. Tropospheric variability and the zonal wave-one, J. Geophys. Res., 108, 8238, doi:10.1029/2002JD002241, 2003.

Thouret, V., Saunois, M., Minga, A., Mariscal, A., Sauvage, B., Solete, A., Agbangla, D., Nédélec, P., Mari, C., Reeves, C. E., and Schlager, H.: Two years of Ozone radio soundings over Cotonou as part of AMMA: overview, Atmos. Chem. Phys. Discuss., 9, 11221-11268, 2009,

http://www.atmos-chem-phys-discuss.net/9/11221/2009/.

Tie, X., Guenther, A., and Holland, E.: Biogenic methanol and its impacts on tropospheric oxidants, Geophys. Res. Lett., 30, 1881, doi:10.1029/2003GL017167, 2003.

Valks, P. J. M., Koelemeijer, R. B. A., van Weele, M., van Velthoven, P., Fortuin, J. P. F., and Kelder, H.: Variability in tropical tropospheric ozone: Analysis with Global Ozone Monitoring Experiment observations and a global model, J. Geophys. Res., 108, 4328, doi:10.1029/2002JD002894, 2003.

Van der A, R. J., Eskes, H. J., Boersma, K. F., van Noije, T. P. C., van Roozendael, M., De Smedt, I., Peters, D. H. M. U., and Meijer, E. W.: Trends, seasonal variability and dominant $\mathrm{NO}_{\mathrm{x}}$ source derived from a ten year record of NO2 measured from space, J. Geophys. Res., 113, D04302, doi:10.1029/2007JD009021, 2008.

Van Aardenne, J. A., Dentener, F. J., Olivier, J. G. J., KleinGoldewijk, C. G. M., and Lelieveld, J.: A $1 \times 1$ degree resolution data set of historical anthropogenic trace gas emissions for the period 1890-1990, Global. Biogeochem. Cy., 15(4), 909-928, 2001.

van der Werf, G. R., Randerson, J. T., Giglio, L., Collatz, G. J., Kasibhatla, P. S., and Arellano Jr., A. F.: Interannual variability in global biomass burning emissions from 1997 to 2004, Atmos. Chem. Phys., 6, 3423-3441, 2006,

http://www.atmos-chem-phys.net/6/3423/2006/.

Villanueva-Fierro, I., Popp, C. J., and Martin, R. S.: Biogenic emissions and ambient concentrations of hydrocarbons, carbonyl compounds and organic acids from ponderosa pine and cottonwood trees at rural and forested sites in Central New Mexico, Atmos. Environ., 38(2), 249-260, 2004.

von Kuhlmann, R., Lawrence, M. G., Pöschl, U., and Crutzen, P. J.: Sensitivities in global scale modeling of isoprene, Atmos. Chem. Phys., 4, 1-17, 2004, http://www.atmos-chem-phys.net/4/1/2004/.

Williams, J. E. and van Noije, T. P. C.: On the updating of the modified Carbon Bond Mechanism IV for use in global Chemistry 
Transport Models, KNMI scientific report WR 2008-02, 64 pp., 2008.

Yarwood, G., Rao, S., Yocke, M., and Whitten, G. Z.: Updates to the Carbon Bond Mechanism: CB05, Yocke and company, Final Report, RT-04-00675, online available at: http://www.camx. com/publ/, 2005.
Yienger, J. J. and Levy II, H.: Empirical model of global soilbiogenic $\mathrm{NO}_{\mathrm{x}}$ emissions, J. Geophys. Res., 100, 11447-11464, 1995. 